\title{
MEINHOF, SHIGENOBU, KENNEDY
}

\section{REVOLUTION ANDASSASSINATION IN 1968}

\author{
Shane O'Sullivan \\ Kingston School of Art, \\ Grange Road \\ Kingston upon Thames \\ Surrey KT1 2QJ \\ United Kingdom \\ s.osullivan@kingston.ac.uk
}

\begin{abstract}
This article reflects on audiovisual representations of the events of 1968 and its aftermath in three national contexts through two archive-driven historical documentaries I have produced exploring this period: RFK Must Die (2008) and Children of the Revolution (2010). RFK Must Die investigates the assassination of Bobby Kennedy through both witness testimony and the hours of network footage available from the crime scene. Children of the Revolution charts the audiovisual historiographies of two female revolutionaries from the 1968 student movements in Germany and Japan to become leaders of the Baader Meinhof Group and the Japanese Red Army. Both women were journalists who used film to fight a propaganda battle against state broadcasters, through collaborations with independent filmmakers or demanding screen time through the television commissioning process. By choosing to frame their stories 'through the eyes of their daughters', who are also journalists, the making of the film became a struggle for editorial control with key contributors and a round of complex negotiations to secure access to archive materials on such a highly-politicized and hotly-contested subject.
\end{abstract}

Keywords: RFK assassination, Bobby Kennedy, Ulrike Meinhof, Fusako Shigenobu, John Pilger, creative reuse, archive clearance, 1968.

\section{Introduction}

Broadcast news relentlessly edits recorded reality to fit the news agenda and the contemporary political narrative but what of the forgotten images judged not fit for broadcast? On the night Robert Kennedy was assassinated at the Ambassador Hotel, Los Angeles in June 1968, the US networks fed hours of live coverage back to their studios. Today, the preserved tapes of these 'live feeds' provide us with CCTV footage of the crime scene. The analysis of this audiovisual evidence provides the narrative engine for my investigative documentary RFK Must Die (2008). What can these unused rushes and unbroadcast live satellite feeds tell us about the past? 
movements in Germany and Japan to dominate the seventies political landscape through anti-capitalist bombings, kidnappings and hijackings. How do the representations of these movements by state broadcasters contrast with the footage of protests shot by independent filmmakers like Roman Brodmann and Koji Wakamatsu? How did Meinhof and Shigenobu engage with broadcasters in the propaganda battle for screen time and fair representation for their movements? How do their journalist daughters use film to protect and control their legacy?

This article uses my films as case studies to reflect on my exhaustive search for audiovisual evidence of these events, discussing the range of surviving archive material available to a documentary filmmaker and the various barriers to access imposed by rights owners and contributors in the US, Germany and Japan. ${ }^{1}$

I explore the use of audiovisual evidence and emerging video technology in the investigation of Robert Kennedy's murder - how video evidence can verify or disprove witness claims, and be an unreliable means of identifying suspects. A filmmaker with a budget to license archive footage is often the only historian allowed access to commercial archives to construct narrative meaning in a database of often poorly annotated material. I discuss my experience of this and the seventies production agreements which constrain the creative reuse of historical footage.

The power of archives and contributors to withhold archive material and cooperation for commercial and political reasons also shapes the structure and content of political history on screen. In Children of the Revolution, the status of Meinhof, Shigenobu and their daughters as journalists ensured the filmmaking process was a complex negotiation as to how key contributions and archival images could be used. Just as the film describes a propaganda battle for screen time and fair representation between Meinhof, Shigenobu and public broadcasters, so the filmmaking process became a struggle for editorial control with Meinhof's daughter, in which the support of my commissioning editor at German public broadcaster WDR was crucial.
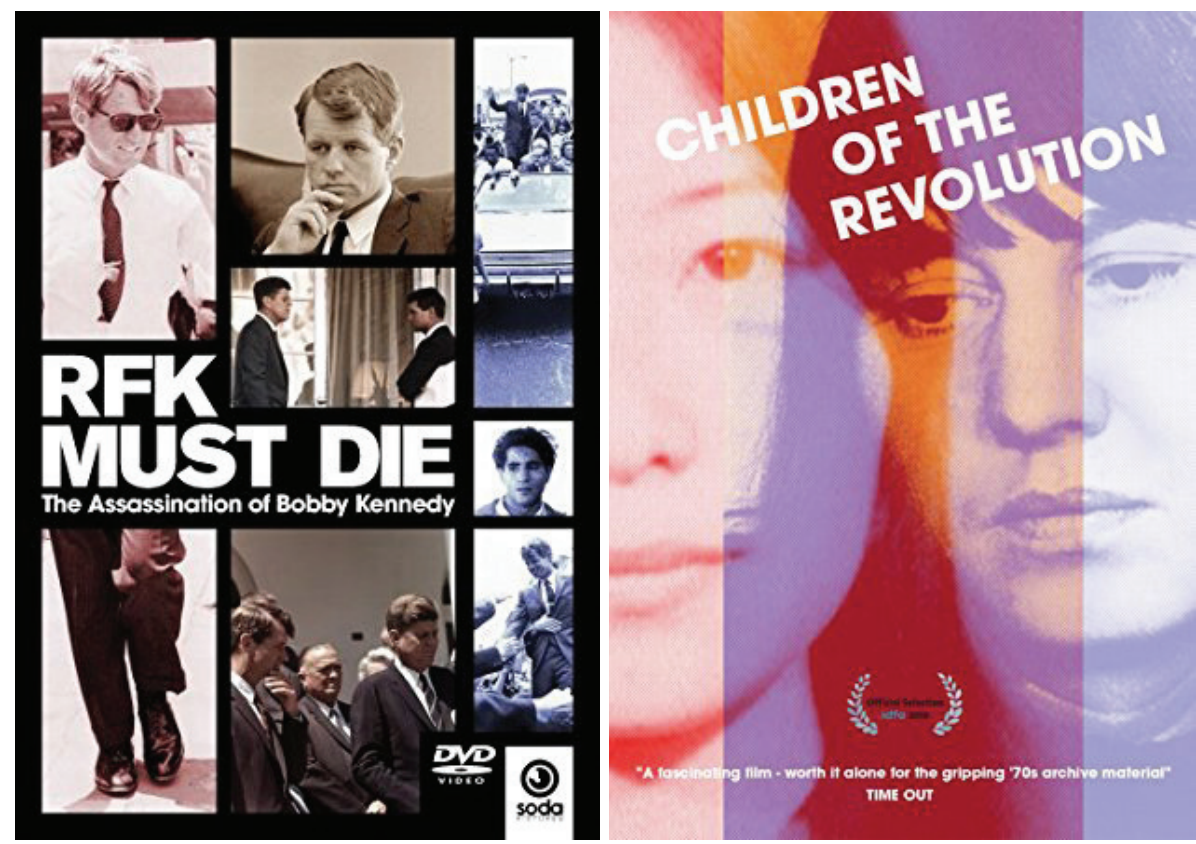

Figure 1. The DVD covers for RFK Must Die and Children of the Revolution. 


\section{Hidden in the Rushes, Lost in the Feed}

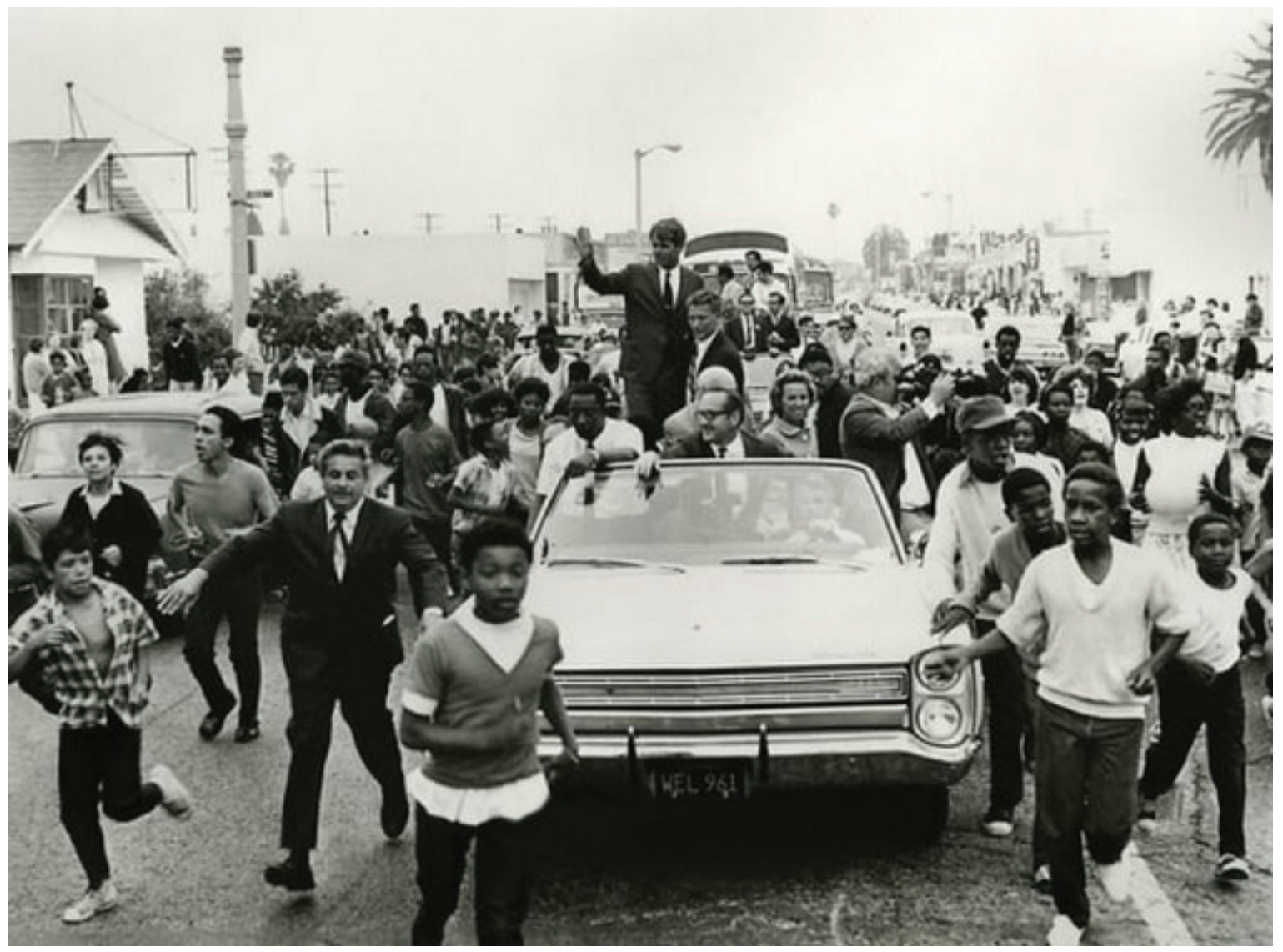

Video 1. RFK Must Die trailer

The moment Robert Kennedy was shot was not caught on camera but the RFK assassination is unique for the sheer volume of film, video and audio evidence recorded at the crime scene before and after the shooting.

It was election night in California, the pivotal Democratic primary that Kennedy had to win to have any chance of taking the Democratic nomination from Vice President Humphrey at the Chicago convention. The U.S. networks reported live from the hotel in the hours leading up to Kennedy's victory speech in the Embassy Ballroom, just after midnight. After the speech, reporters and camera teams followed Kennedy off the podium and through a narrow, dimly lit kitchen pantry towards a late-night press conference. ${ }^{2}$

But, crucially, the portable $16 \mathrm{~mm}$ news cameras were not rolling as the shots rang out. By the time Jim Wilson of CBS heard the shots and jumped through the pantry doorway with his camera, Kennedy was lying in a pool of blood on the floor, his head cradled by a young Filipino busboy in a tragic tableau that became the iconic image of the assassination. 


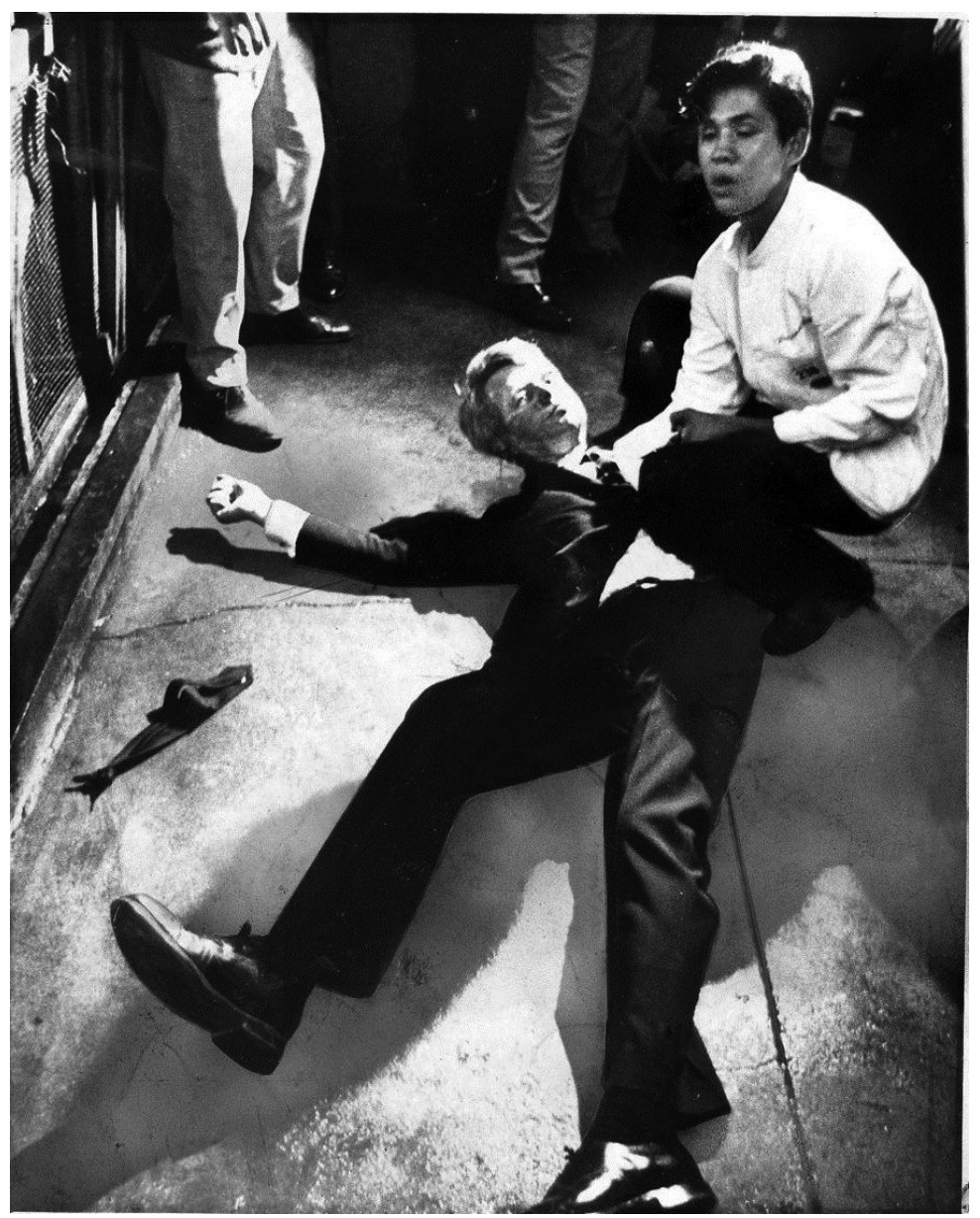

Figure 2. Juan Romero tends to Robert Kennedy after the shooting (Boris Yaro/L.A. Times).

Camera teams from all major networks and local affiliates were filming at the hotel that evening. Aside from the newsfilm shot by mobile cameramen like Wilson and the 'aircheck' recordings of live broadcasts by the networks and their local affiliate stations, there were also unbroadcast 'raw feeds' transmitted from multiple fixed video cameras inside the Ambassador Hotel to outside broadcast units and recorded to two-inch videotape. ${ }^{3}$

Within hours of the shooting, J. Edgar Hoover's assistant at the FBI 'desired that all the CBS and NBC television films be secured and reviewed for any possible suspects...[and] to review and identify all suspicious persons in the film,' even though 'the individual [Sirhan Sirhan] who did the shooting was already in custody.' When it was pointed out 'that TV film is video tape and to transcribe it into black and white film suitable for movie projection would cost ten cents a running foot,' approval was given, 'if this cost were necessary.' ${ }^{4}$ The agent was asked to secure 'additional personnel to handle this phase at the studios. ${ }^{5}$

When key witnesses were interviewed on a local TV show later that day, the costly videotapes of the broadcasts were erased and reused before the FBI could request a copy twelve days later. ${ }^{6}$

3 I was first alerted to the existence of these 'live feeds' by former CNN journalist Brad Johnson, who negotiated access to them for a CNN project before I began work on my film.

4 Supervisor William John Nolan to SAC, Los Angeles, 5 June 1968, RFK Assassination Documents - FBI Los Angeles Field Office Files, Maryferrell.org. 5 lbid.

6 FBI memo to SAC, Los Angeles, 18 June 1968, FBI LAFO Files, Maryferrell.org 
Within hours of the assassination, in a live NBC interview, witness Sandra Serrano described a girl in a polka dot dress seen fleeing the hotel, exclaiming:

\section{We shot him! We shot Kennedy!}

Two days later, the president of NBC affiliate station KRON wrote to Chief Reddin at the Los Angeles Police Department (LAPD), explaining how 'the inspection of television recordings' might help him identify the elusive girl:

All three networks probably have video tape recordings of activities outside the Ambassador Hotel and in the public rooms used by campaign staff and workers. It is also possible these recordings include 'out time' which would be views of these areas not actually broadcast but which were on a stand-by basis awaiting switching to the main broadcast circuits. ${ }^{7}$

He highlighted the thousands of feet of film 'in the hands of networks and various other news agencies and independent production agencies' that Miss Serrano could view to 'possibly spot the woman by her distinctive clothing. ${ }^{8}$

Three days later, the news directors of seven local TV stations were called and asked to retain 'all films and video tapes of the Kennedy shooting' but there is little evidence in LAPD files that this video material was viewed. ${ }^{9}$

The video cameras at the back of the ballroom and at various locations around the hotel had less evidentiary value than the film cameras that followed Kennedy into the pantry but most of this footage seems to have been ignored at the time.

There were exceptions. Investigators did use a 'live broadcast' videotape of CBS affiliate KNXT to establish the exact times Kennedy entered and left the stage, synchronizing clock times for a commercial broadcast by KNXT and logged by the Federal Communications Commission shortly before midnight. Kennedy turned to leave the stage at 12.14.47 a.m. and the shooting erupted in the kitchen pantry one minute and twelve seconds later. ${ }^{10}$

The day after the shooting, witness Patricia Nelson told the FBI she saw a slightly-built Mexican or Cuban man running out of the Embassy Room after the shooting with what looked like 'the stock of a gun protruding from a package.' Two friends were with her and one of them spotted the same individual in footage replayed on an ABC newscast later that evening. ${ }^{11}$

The FBI made arrangements for Nelson and her friends to view the newscast at $A B C$. In the meantime, 'ABC film editors, in searching video tapes on the Kennedy affair had frozen a frame of the person carrying the package... [thinking it] could have been Sirhan Sirhan.' The tape shows Kennedy signing rolled-up campaign posters for a Sirhan lookalike later identified as Michael Wayne, on his way to the stage. Seeing the rolled-up posters again on tape caused Nelson to doubt her initial impression that a gun was hidden in them and the FBI took no further action. ${ }^{12}$

Nine days after the shooting, the LAPD's case preparation team had viewed the films from ABC and CBS and was obtaining NBC material from the FBI. A crude twenty-minute compilation reel of the key events before and after the shooting was made, featuring murky, ungraded film footage. A later memo notes that 'an eventual video-tape reconstruction is planned' but this apparently never happened. ${ }^{13}$

\footnotetext{
7 Letter from Harold See to Chief Reddin, 7 June 1968, Special Unit Senator LAPD Collection, Maryferrell.org. 'Being done' was written on the letter 13 days later.

8 Ibid.

9 Rampart Detective Division note on TV stations called on 10 June 1968, SUS LAPD Collection, Maryferrell.org

10 LAPD report on Cecil Lynch, 18 June 1968 and LAPD Final Report, 144, SUS LAPD Collection, Maryferrell.org

11 FBI interview with ABC News Director William McSherry, 8 June 1968 and FBI memos to SAC, Los Angeles, 10 June 1968 and 14 June 1968 ,

FBI LFO Files, Maryferrell.org

12 Ibid.

13 Louise Foster LAPD report, 14 June 1968, SUS LAPD Collection, Maryferrell.org
} 


\section{1 'If It's Not in the Online Database, We Don't Have It'}

As Errol Morris notes:

History is perishable. It depends on evidence. There are countless stories where evidence is lost, corrupted or hidden, and hence, our attempts to re-assemble a picture of reality are doomed at best. ${ }^{14}$

When historical research centres on a murder case, the search for new or neglected audiovisual evidence of the event in the archives is a key aspect of any cold case investigation.

During the production of RFK Must Die (2008), I could never take what archive sales people were telling me at face value because I knew, in many cases, they were wrong. Their mantra seemed to be 'If it's not in the online database, we don't have it.' The sales manager at NBC News Archives said: 'The network was NOT on air at the time of the assassination, so there is no off-air 'live' recording of the 'On to Chicago' victory speech, followed by the shooting...'

In fact, according to former CNN journalist Brad Johnson, NBC was indeed live on air at the time of the assassination, and was the only one of the three major US networks broadcasting a live report from the hotel during the shooting. In 2004, Johnson began an exhaustive search for all audiovisual footage recorded at the Ambassador Hotel that night for a CNN-approved project. According to Johnson's extensive archive of network material:

NBC News Correspondent Charles Quinn was in the ballroom still doing a live wrap-up of RFK's victory statement while the gunshots were being fired off-camera and off-mic in the kitchen service pantry. Quinn did not know the shooting was taking place and went ahead with his live toss back to NBC News Anchor Frank McGee at the network's studios in Burbank. At the time of the RFK shooting, NBC was providing a nationwide anchored broadcast. ${ }^{15}$

\subsection{What the Video Evidence Tells Us}

Brad Johnson was the first researcher to discover the existence of these preserved 'live feeds' from the night of the assassination and examine them as evidence. Johnson used his professional status to conduct a comprehensive search of the network archives and when I undertook a similar search for the BBC Newsnight broadcast that led to my film, we shared our knowledge, drawing on over one hundred hours of film and video footage shot inside the hotel that evening.

Our professional media status gave us access to material in commercial archives that is simply not available to researchers and historians unable to license broadcast material, and our persistence uncovered hidden layers of archive footage that salespeople at many of the archives didn't know existed.

Our examination of these hundred hours of archive was comparable to a detective wading through CCTV footage of a crime scene - Princess Diana leaving the Ritz or the terrifying hotel-security footage of the Mumbai attacks - tracking the movements of key suspects throughout the evening, looking for clues that would unlock unresolved aspects of the

14 'Morris Commencement Address,' UC Berkeley Graduate School of Journalism, 10 May 2010, https://journalism.berkeley.edu/film-legenderrol-morris-salutes-new-graduates-201/

15 Brad Johnson email to author, 14 June 2015. 
investigation. Cross-referencing clock-times on broadcast tapes, Brad established exact timings for this footage, giving us an invaluable chronology of the event - who was where when, and how this fit with their witness testimony.

This led to important discoveries: new film of alleged bullet holes in the pantry doorframes which indicated more than eight shots were fired and a second gunman was involved; and video of security guard Thane Eugene Cesar, a key suspect, patrolling the hotel after the shooting. Brad Johnson rediscovered the only known audio recording of the shooting by Polish reporter Stanislaw Pruszynski. Network footage tracked his movements from the stage towards the pantry area as his cassette recorder captured the gunshots and was vital to the subsequent forensic audio analysis which concluded thirteen shots were fired in the pantry from two guns. ${ }^{16}$

My film was inspired by archival images of three alleged CIA agents at the Ambassador Hotel that evening, identified by former CIA and State Department colleagues and Congressional investigators. The latter part of the film is driven by my quest to positively identify these agents beyond reasonable doubt and verify my working hypothesis that they were involved in the assassination.

The perils of searching for meaning in archive fragments of this nature are well illustrated in Errol Morris' 2011 short for the New York Times, The Umbrella Man. Author and investigator Josiah Thompson gives an illustrated discussion of a mysterious figure visible in the Zapruder film holding up a black umbrella on a sunny day - a man he dubbed in 1967 'The Umbrella Man':

In all of Dallas, there appears to be one person standing under an open black umbrella, and that person is standing [right] where the shots begin to rain into the limousine...Can anyone come up with a non-sinister explanation for this?

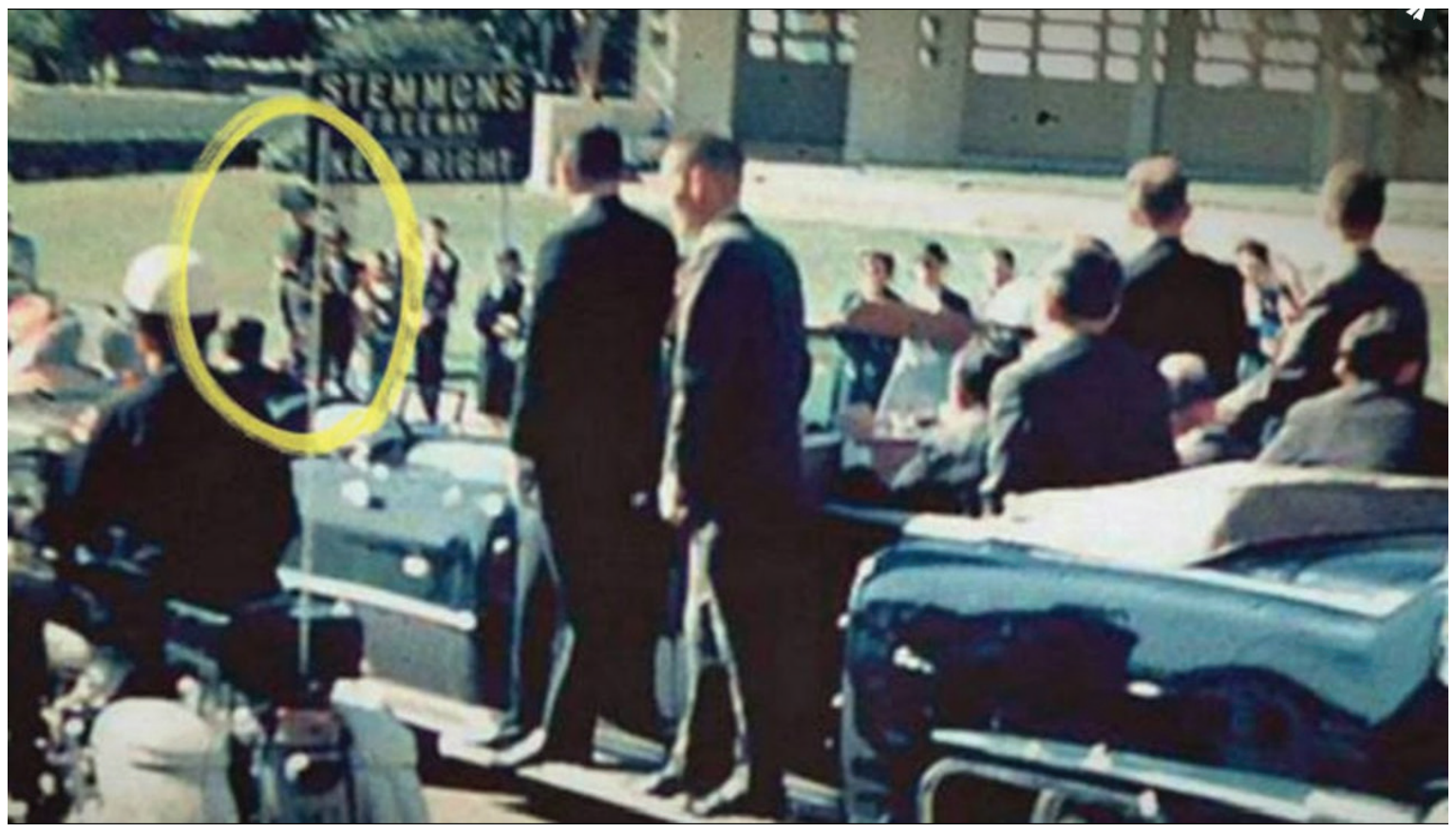

Video 2. The Umbrella Man

16 The new film of alleged bullet holes in the pantry doorframes was located in Hearst footage at the UCLA Film and Television Archive. CBS News footage depicts Cesar after the shooting. A long-neglected copy of the Pruszynski recording was digitized at California State Archives and ABC News footage establishes Pruszynski's location in relation to the pantry as his tape recorder captured the sound of the gunshots. 


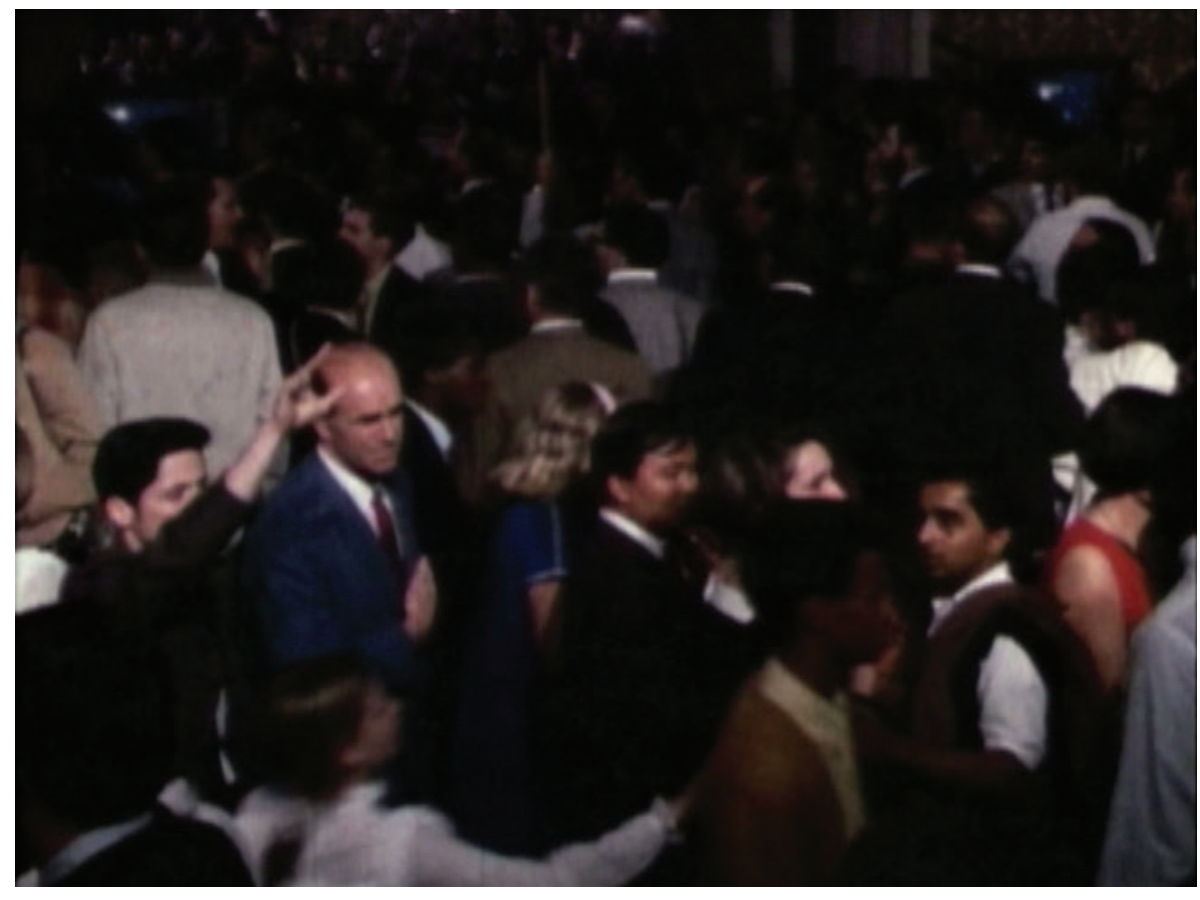

Figure 3. Still frame from RFK Must Die (2008)

The most dramatic piece of archive in my film initially appeared to show senior CIA officer Gordon Campbell emerging from the pantry into the ballroom and being directed towards an exit while holding his right hand horizontally across his chest. Was he carrying a weapon from the scene or did this odd mannerism merely appear sinister when loaded with other information?

After my initial piece on the men for BBC Newsnight, new witnesses and evidence emerged and the theory started to unravel. After further research, I identified two of the men as salesmen for the Bulova Watch Company, at the hotel for a sales meeting. Network footage of 'Campbell' at other times and from other cameras confirmed he was not in the pantry and higher-resolution master footage showed he was not carrying anything in his hand.

The misidentification of Campbell and Joannides highlights the dangers and subjective nature of photo identification from memory decades after the fact. While former CIA agent Bradley Ayers and former US diplomat Wayne Smith continued to stand by their identifications, I was no longer convinced.

\subsection{The Man Who Wasn't There}

15-year-old Scott Enyart claimed he was in the Ambassador Hotel pantry with his stills camera, taking photographs of Robert Kennedy at the moment Kennedy was shot. If true, these missing images would represent the lost Zapruder Film of the Bobby Kennedy assassination. ${ }^{17}$

Enyart claims the LAPD confiscated his camera at gunpoint that night and gave him back 26 prints from a 36 -exposure roll after the trial. The prints didn't include the photos allegedly taken in the pantry and when the LAPD investigation files on the case were opened in 1988, Enyart's photographs were 'missing.' A destruction order dated 


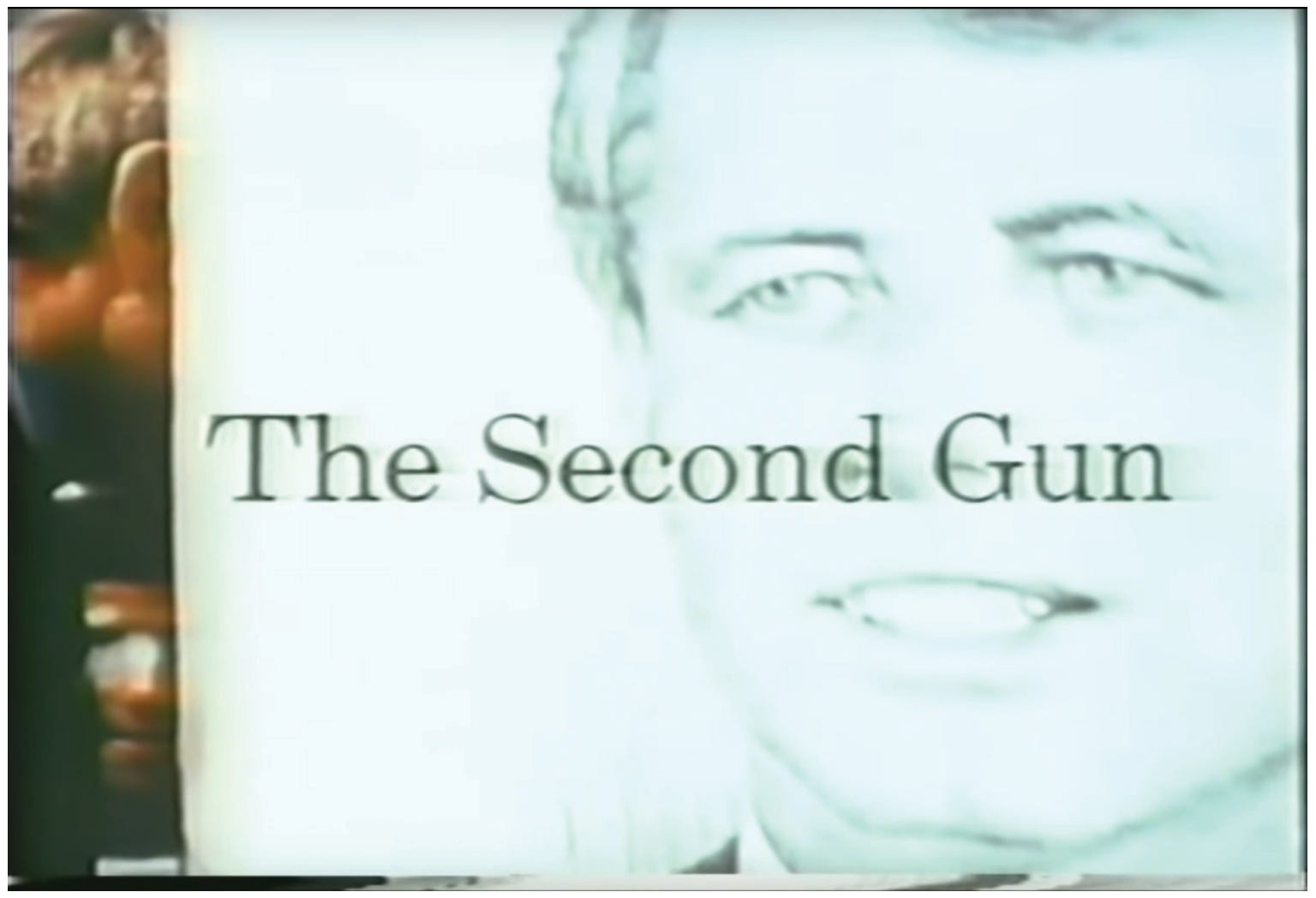

Video 3. Scott Enyart clip from The Second Gun (1973)

August 1968 revealed 2400 photographs had been incinerated and the state archivist initially believed Enyart's may have been among them. ${ }^{18}$

In 1989, Enyart filed a two-million-dollar lawsuit against LAPD for the missing photos but during trial preparation in 1995, thirty prints were found at California State Archives - they had been misfiled. The images Enyart claimed he shot in the pantry were still 'missing' and he was awarded $\$ 450,000$ in damages, a judgment later reversed due to anti-police bias by the jury. ${ }^{19}$

Network footage debunks one of the most notorious alleged incidents of LAPD destruction, clearly placing Enyart in the Embassy Room, where his friend Brent Gold said he was, five seconds before the shooting started and two minutes after it stopped. While there is a two-minute gap in the audiovisual record, Enyart was walking away from the pantry five seconds before the shooting and looking around, confused, in the ballroom afterwards, making it almost impossible for him to have been briefly in the pantry and taken the photos he described.

Even esteemed journalists like John Pilger are not averse to embellishing their place in history. As a Daily Mirror reporter, Pilger watched Kennedy's speech in the Embassy Room of the Ambassador Hotel that night. In 2007, in a piece on the 'Kennedy myth,' he wrote, 'As a witness to such times and events, I am always struck by self-serving attempts at revising them...'

He goes on to describe a woman standing next to him shouting 'He's the next President Kennedy!' after Kennedy's victory speech. 'She then fell to the floor with a bullet wound to the head,' he writes. The woman was Elizabeth Evans, 
who was in the kitchen pantry, far from Pilger when she was shot. Pilger derides Bobby Kennedy as an 'opportunist par excellence' but takes his own liberties with his colourful yarn. ${ }^{20}$

A year later, in an interview on the fortieth anniversary of the assassination, Pilger went even further:

There's no question that there was another gunman, because one of the people who was hit, just grazed, was standing next to me, and that happened when Sirhan Sirhan had been wrestled to the ground. ${ }^{21}$

He claims he followed Kennedy into the kitchen pantry, describes the shooting as if he witnessed it himself, says he told the FBI how many shots he heard and even thought he saw the famous woman in a polka dot dress - Sirhan's alleged accomplice - fleeing the scene..$^{22}$

In fact, according to police and FBI reports of interviews with Pilger, he was in the main ballroom at the time of the shooting and $C B S$ and $A B C$ network footage confirms this. He can be seen walking through frame just seconds after news of the gunshots spreads panic and hysteria through the crowd. Four minutes later, he is chatting with the Daily Mirror's George Gale in the middle of the ballroom. According to Gale, Pilger said of the crowd, "Look at them. They're hysterical. It's like Sinatra!" In Pilger's report for the Daily Mirror the next day, he places himself "less than 100 ft." from the entrance to the kitchen, contradicting his later claims. ${ }^{23}$

The assassination of Robert Kennedy is a case where the LAPD - and later, the City of Los Angeles, in defending itself against Scott Enyart - didn't make full use of the audiovisual evidence available. A filmmaker working within an archive collection can construct important narrative threads between seemingly disparate material to enhance or transform our understanding of a historical event. The time pressures and editorial constraints of a commercial project work against the knowledge created by an archive researcher being recorded or shared for future use by a competitor. Filmmakers and academics have an important role to play in helping under-resourced archives excavate lost stories buried in their collections to harness their hidden cultural value.

My take-away from this archive search is that filmmakers have a unique role to play in rediscovering important visual evidence of the past. Their professional status provides access and their interest in licensing material gives archives a commercial incentive to index and digitise footage that has often been lying dormant in film cans since the day it was processed.

Filmmakers and their research teams bring an informed eye and a depth of subject knowledge to the footage. They know what they're looking for and can find clues in the metadata which bring sense and order to hours of seemingly random footage and enable important discoveries.

This evolving knowledge base around the audiovisual record of a subject can be shared with other filmmakers, as I did with Brad Johnson, advancing collective knowledge and producing better-informed documentaries.

The relationship between filmmakers Adam Curtis and Göran Olsson and the archives of national broadcasters BBC and SVT respectively, has produced immersive, provocative found footage meditations on historical themes, drawing on the richness of public broadcast archives and demonstrating their cultural importance and untapped educational value. Sheffield Doc/Fest's annual archival collaborations with the BFI and an invited filmmaker on films like From the Sea to the Land Beyond have similarly captured the public imagination.

20 'Robert Kennedy: Another legacy, another myth,' The New Statesman, 14 May 2007.

21 'Democracy Now! Special: Robert F. Kennedy's Life and Legacy 40 Years After His Assassination,' 5 June 2008, https://www.democracynow. org/2008/6/5/democracy_now_special_robert_f_kennedy

22 Ibid.

23 John Pilger, 'No! Shouted Kennedy As He Saw the Gunman,' Daily Mirror, 6 June 1968; Steve Myall, 'How did Bobby Kennedy die?', Daily Mirror, 26 April 2018, https://www.mirror.co.uk/news/world-news/who-killed-bobby-kennedy-assassination-12426359 
This work suggests an important role for filmmakers and academics in helping commercial archives map the historical connections between fragments of the past within and across collections and archives. Many digital collections already allow users to suggest corrections to metadata. More formal filmmaker-in-residency schemes would accelerate this process, creating new knowledge within collections.

\section{Children of the Revolution}

My second feature documentary, Children of the Revolution (2010) explores the personal and political histories of two women who emerged from the student revolutions of 1968 to become the leading voices of revolutionary struggle in Germany and Japan - Ulrike Meinhof and Fusako Shigenobu. Working closely with an archive consultant at WDR and German and Japanese-speaking researchers, I began to piece together the screen historiographies of Meinhof, Shigenobu and their movements in broadcast archives and through the work of independent filmmakers.

Meinhof entered the field of cultural production in the late fifties when her writing and speeches within the student anti-nuclear movement brought her to the attention of konkret editor Klaus Rainer Röhl, whose influential magazine was secretly funded by the East German Communist Party. Röhl gave Meinhof the platform of a regular column in 1959, providing her main outlet of expression for the next ten years.

Meinhof married Röhl and gave birth to twin-daughters Bettina and Regine in 1962. She quickly developed into the star-columnist and opinion-leader for konkret, with provocative articles like Hitler Within You (1961) detecting Nazi echoes in the fascist tendencies of Defence Minister Franz Josef Strauss.

As Meinhof's symbolic capital grew, she diversified into television, making three short films on social issues for NDR in 1965 and several radio features. Her first appearance in front of the camera came in WDR's Hier and Heute political discussion programme the same year. It's interesting not so much for what she says - on an obscure topic

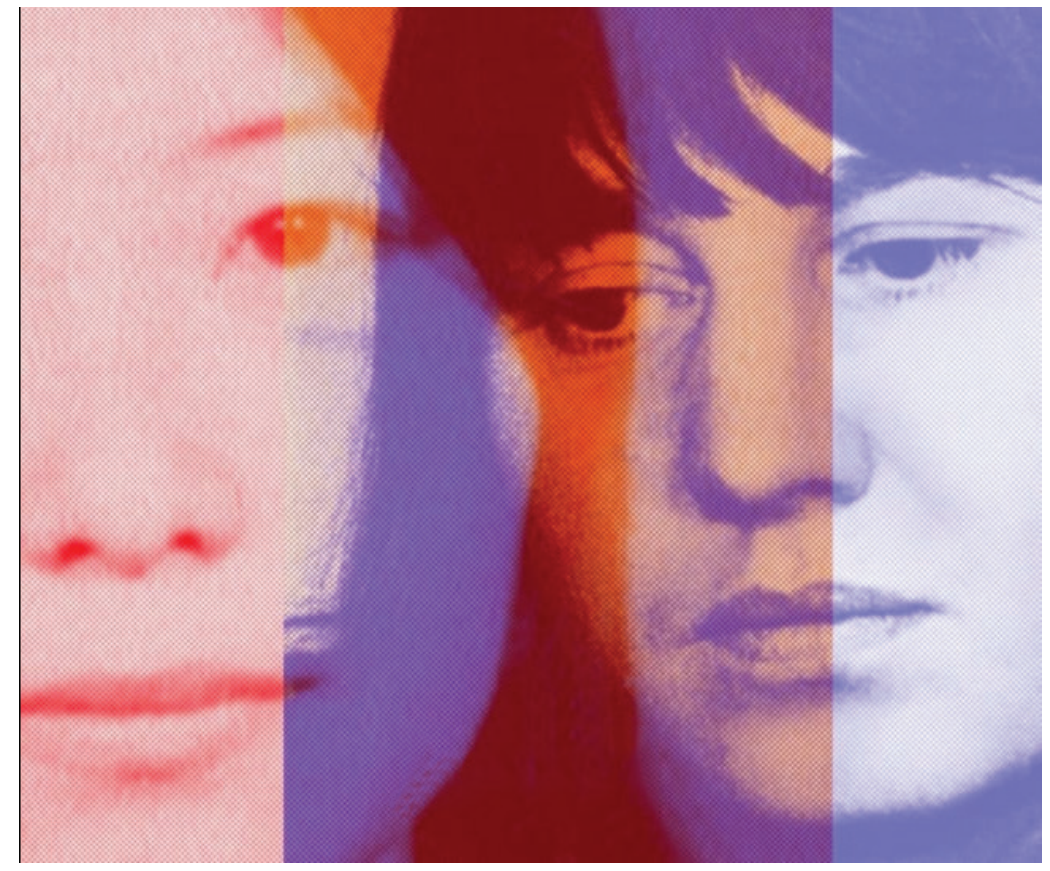

Video 4. Children of the Revolution trailer 


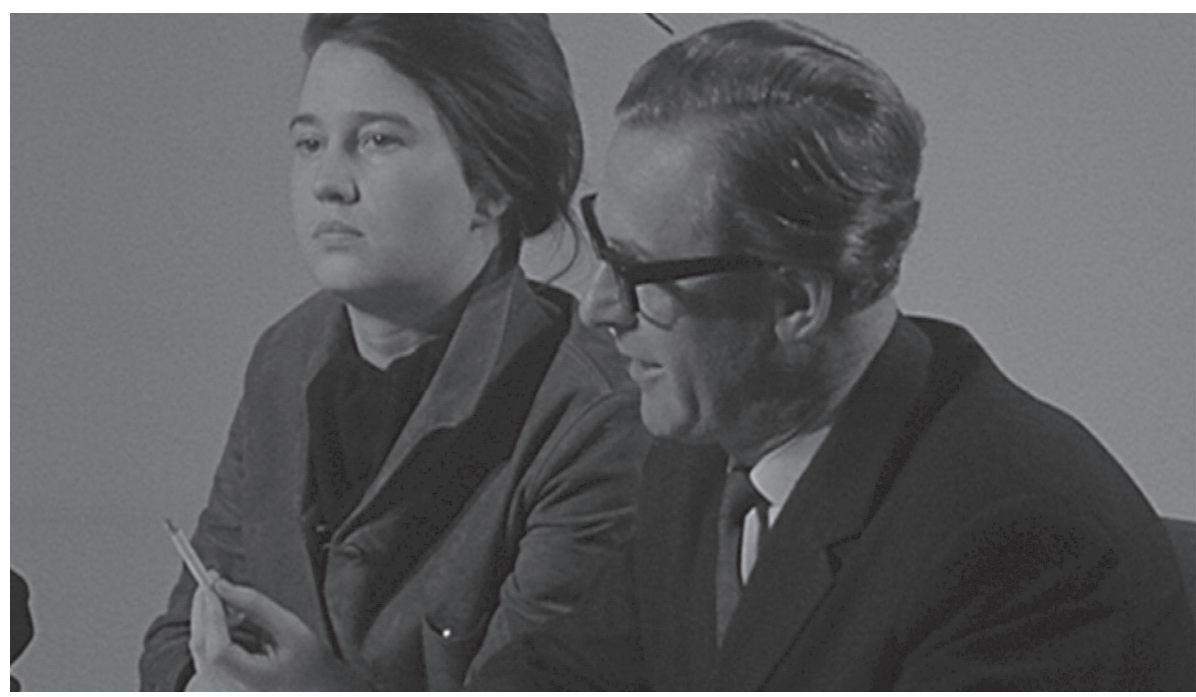

b

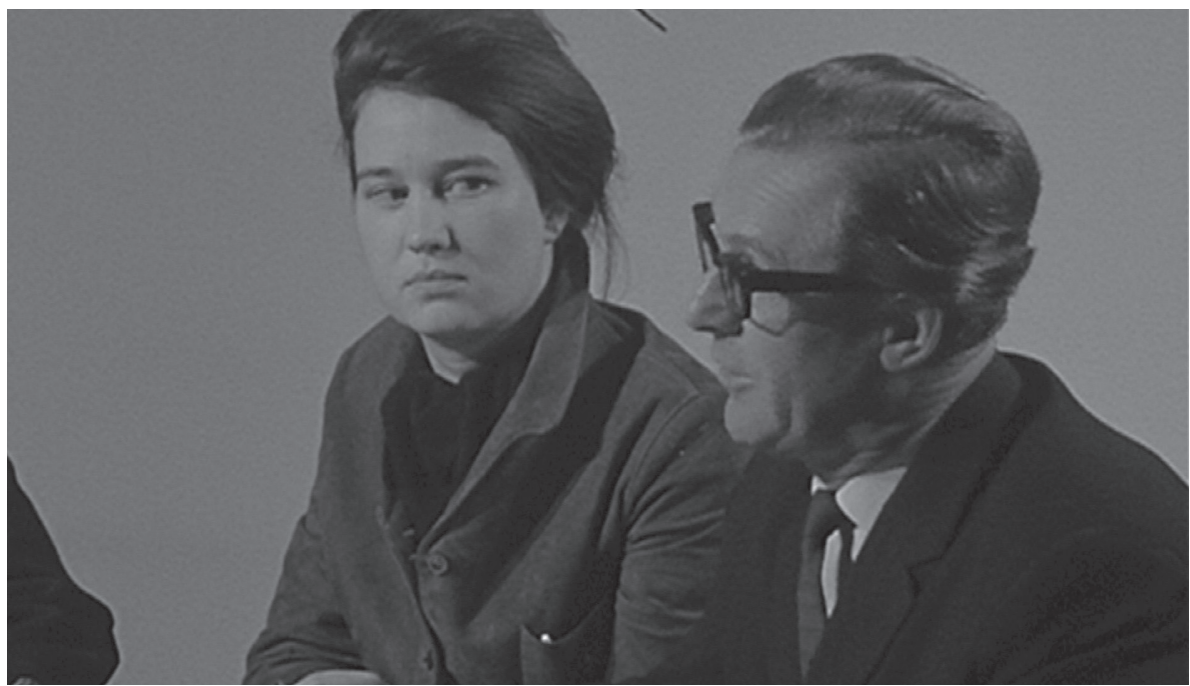

Figure 4 a-b. Still frames from Hier and Heute (WDR, 1965).

not relevant to my film - but as an opportunity to observe Meinhof in wide shot, smoking, listening and thinking, an incongruous young woman sitting on a panel with three older men.

Roman Brodmann's film, The Police State Visit ('Der Polizeistaatsbesuch', 1967) captures the baroque preparations for the visit of the Shah and his wife to Berlin in June 1967, and the anti-Shah demonstrations that prompted his henchmen to beat student protestors with sticks as German police stood by, taking pictures of demonstrators.

Karl-Heinz Kurras, a police officer with links to the Stasi shot student protestor Benno Ohnesorg dead that night, igniting the 1968 movement in Germany. Kurras claimed he was acting in self-defence but forty-five years later, enhanced newsreel footage depicted Kurras calmly approaching Ohnesorg with a pistol in his hand and newlydiscovered photographs showed Kurras' superior standing nearby. ${ }^{24}$ 


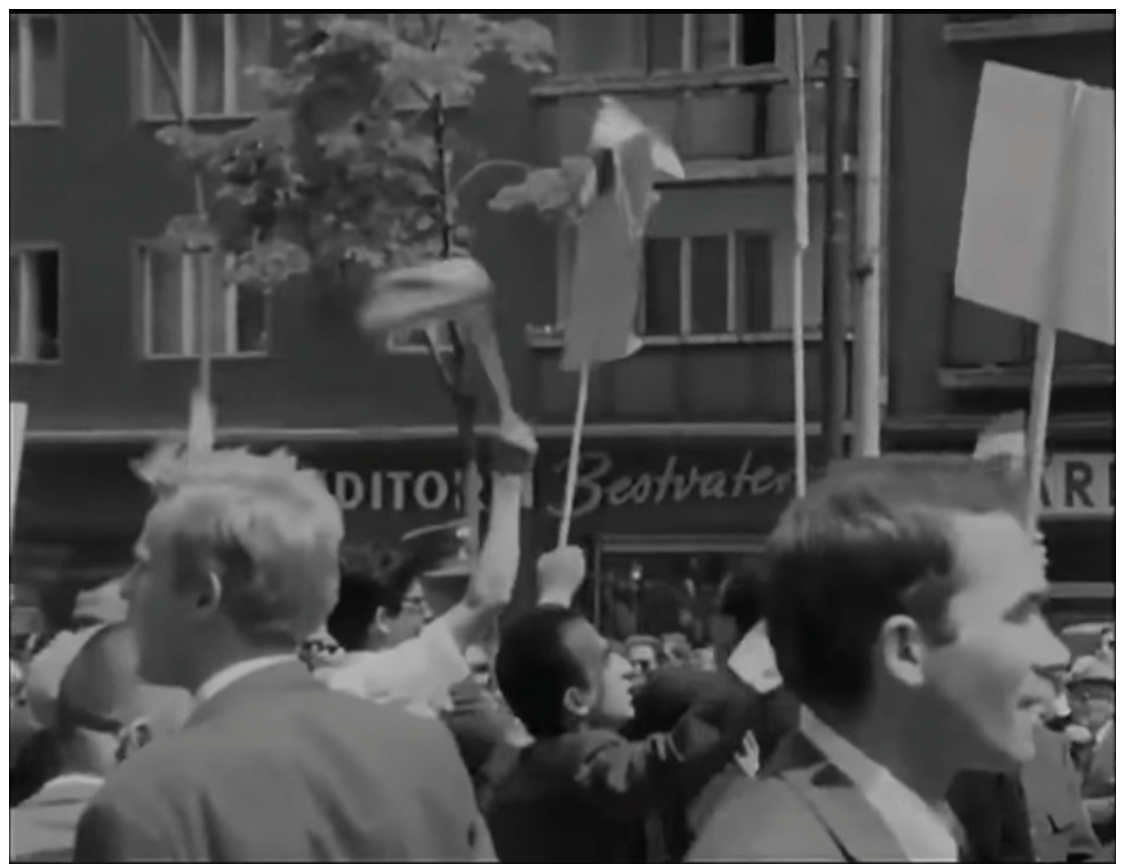

Video 5. The Police State Visit

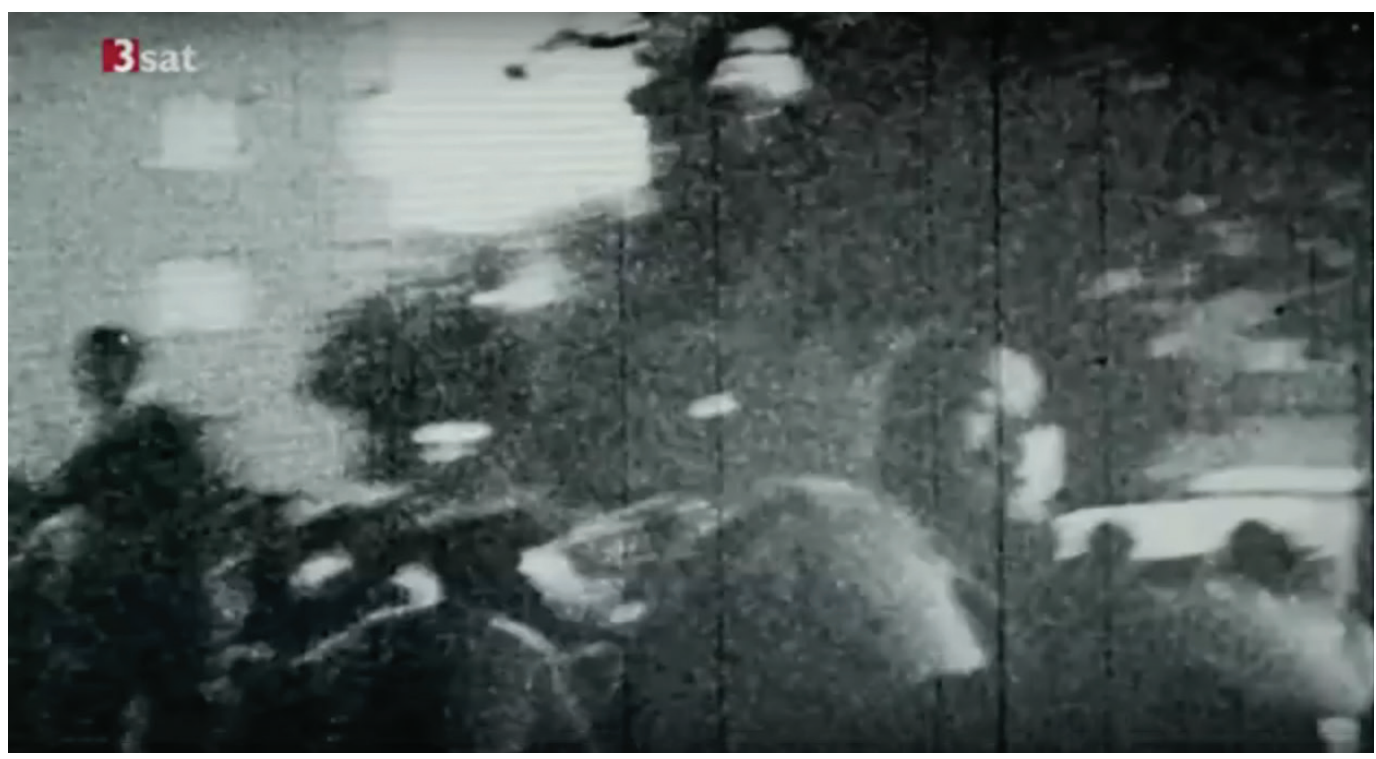

Video 6. The Murder of Benno Ohnesorg (2012)

After a ferocious open letter to the Shah in konkret, Meinhof was invited to make a film about the Shah's disastrous visit to preface a televised debate in February 1968, wedding the voice of her column to images from Brodmann's film:

Protests against the head of a police state revealed our own state to be a police state. The police and media terror hit its peak on June 2 in Berlin. We saw that freedom in this state is freedom for the police truncheon. And freedom of the press in the shadow of Springer Corporation is freedom to justify the truncheon. ${ }^{25}$ 


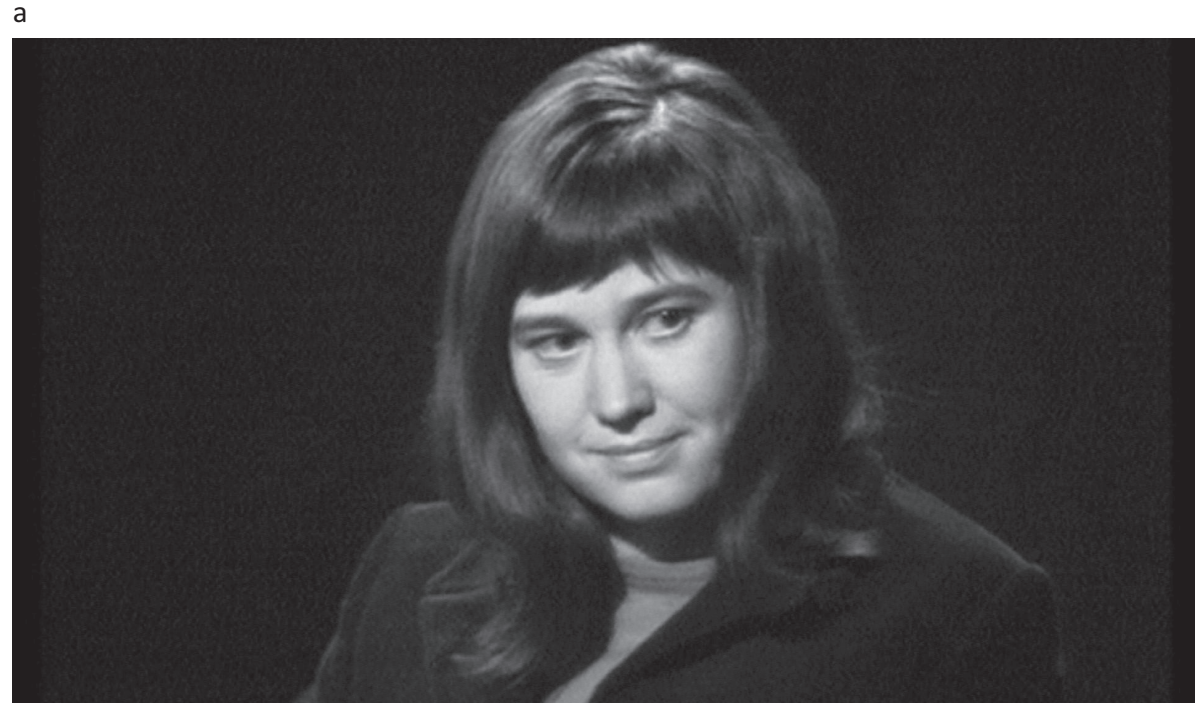

b

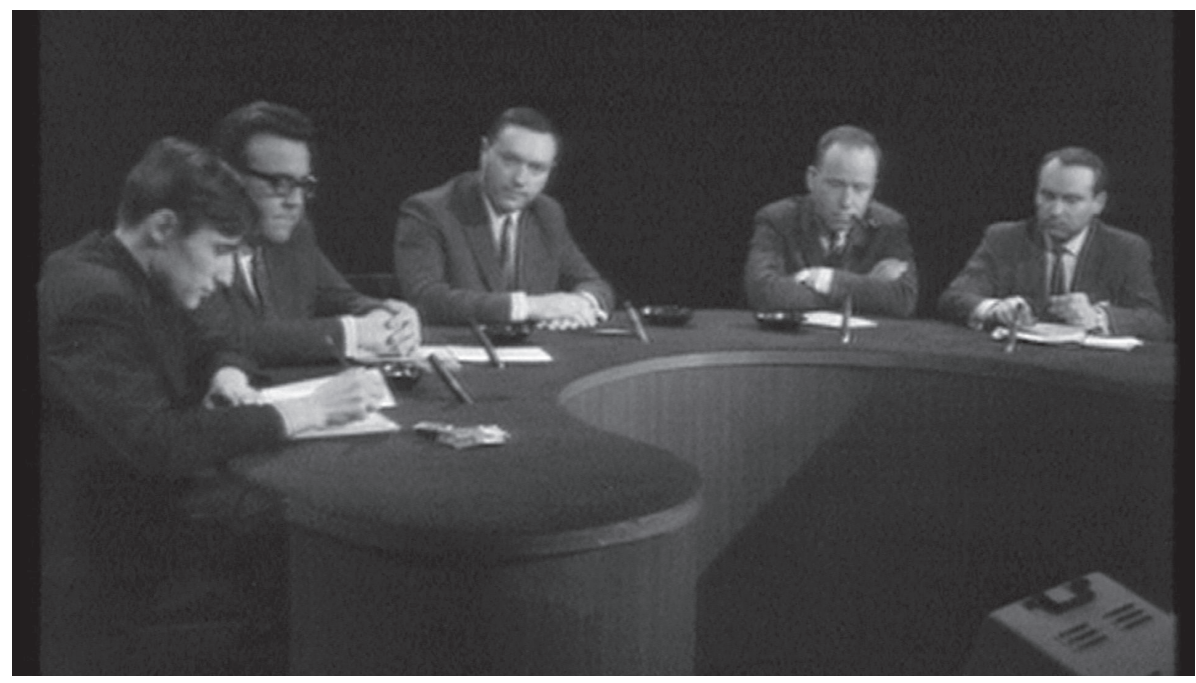

Figure 5 a-b. Still frames from Bessere Demokraten oder Anarchisten (SFB/RBB, 1968).

In the ensuing studio debate, five men in suits sit slumped around a convex table as the charismatic Meinhof assails them, in medium close-up, on behalf of the Extra-Parliamentary Opposition (APO), a student alliance demanding freedom of expression from a government enacting emergency laws to clamp down on street demonstrations:

I definitely don't consider the streets a very suitable means of making our views known. But if we have no further options... If we don't have 1-2 hours of TV time once or twice a week to say what we think. If we don't have Springer's millions of papers, magazines; if we face bans whenever we try to meet and talk in public... ${ }^{26}$

Meinhof knew access to the 'public space' - in Bourdieu's understanding of the term - through television was far more effective than street demonstrations but, denied a weekly slot and a channel of diffusion, she soon pursued a more extreme strategy, as foreshadowed in the television debate: 'We support those seeking freedom from terror and violence. If war is their only means, we will support that war. ${ }^{27}$ 


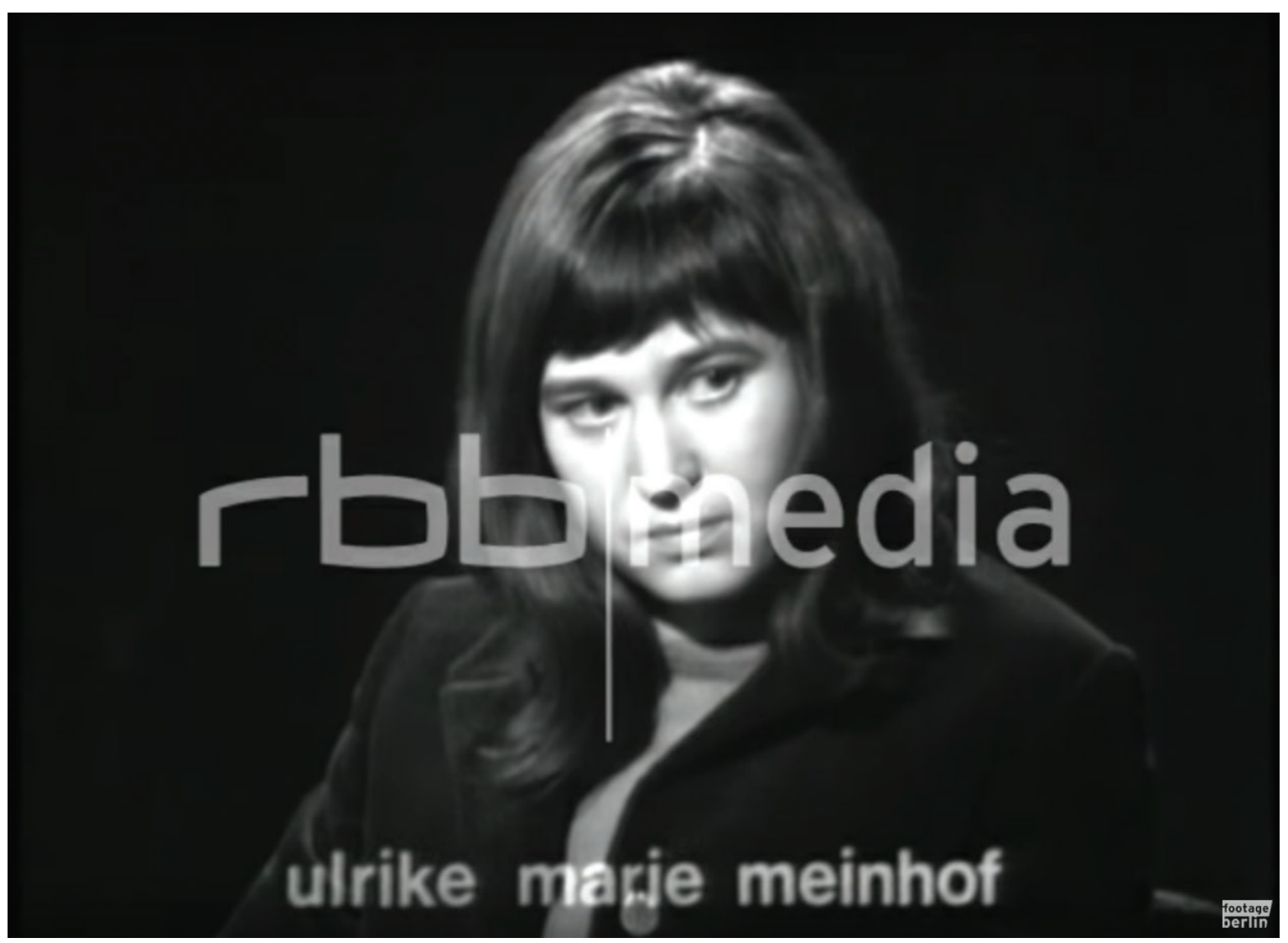

Video 7. Meinhof studio debate

On May 5, 1968, she published her most famous column, From Protest to Resistance, marking a turning point in her move from revolutionary theory to practice: 'Protest is when I say I don't like this. Resistance is when I stop what I don't like.' In early 1969, Meinhof published her final column, Columnism, analysing her role as konkret's star columnist and her battle with her editor and former husband Klaus Röhl to move from an individual voice to collective action:

Columnism is a personality cult. Through columnism, the left-wing position that was developed...in the move from theory to practice in the summer of $1967 \ldots$... reduced...to the views of an original, outrageous, nonconformist individual, who can be co-opted because in being alone they are powerless. ${ }^{28}$

Just as Godard turned from auteur cinema towards the collective practice of the Dziga Vertov Group, so Meinhof rejected the brand leadership imposed on her by konkret in its drive to trade radical chic and progressive editorial for lucrative advertising space and a profitable niche within the existing capitalist model.

A Panorama report from May 1969 shows Meinhof leading a student group from Berlin to Hamburg to attack the offices of konkret, and, when that fails, to trash her former home with Klaus Röhl. Yet behind the brash public image, Meinhof cut an isolated figure - a single mother in Berlin, alone with her twins and torn between private life and 


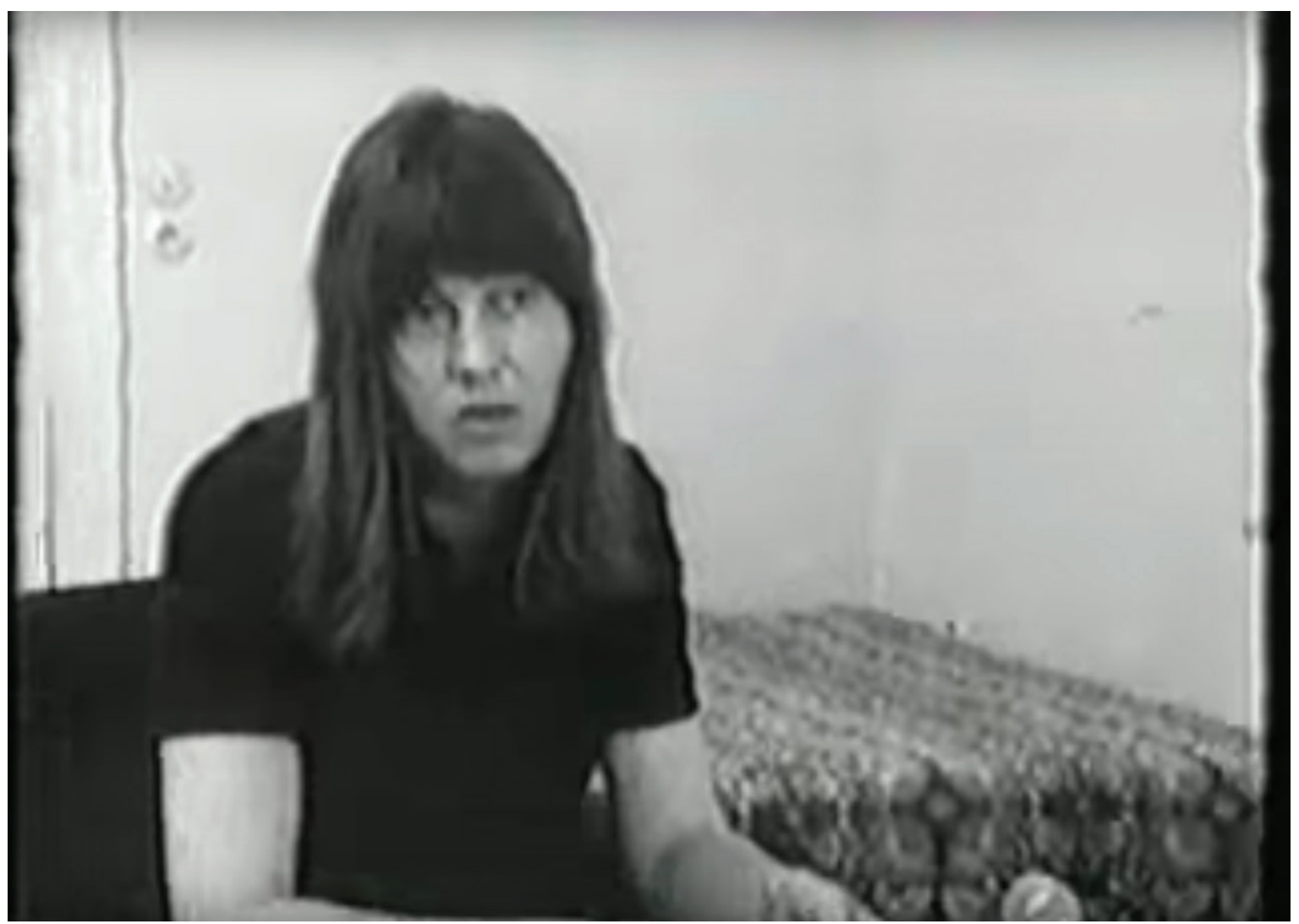

Video 8. Extract from She - Journal for Women (1969). ${ }^{29}$

political action - as seen in her most intimate and revealing interview, a short feature for WDR's She - Journal for Women (1969) broadcast eleven days after the attack in Hamburg and the first clip of Meinhof we see in my film:

A problem that every politically active woman faces, myself included, is that she works for society, she has the right ideas, maybe knows, how to talk, write, take action...but she is as disarmed with her children, as all women are.

This clip captures the central dilemma of the protagonists in my film and is also emblematic of the complexities of locating, clearing and licensing archive material for a film like Children of the Revolution. As noted in a previous article (O'Sullivan, 2013), 'the initial search [for images] is largely dependent on the quality of the metadata... associated with relevant holdings in an archive's database.' I spent many months searching for the source of Meinhof's most revealing interview before finding it tagged 'Ulrike - Konkret' rather than 'Ulrike Meinhof' in the WDR database. ${ }^{30}$

One of my most valuable finds in the archive was an extraordinarily frank interview with Meinhof's ex-husband Klaus Röhl on a late-night WDR talk-show (Je später der Abend, 1973). Sitting in a TV studio two kilometers from Meinhof's prison cell on her thirty-ninth birthday, he describes her mistreatment in an isolation cell and the effect of her imprisonment on the children. 

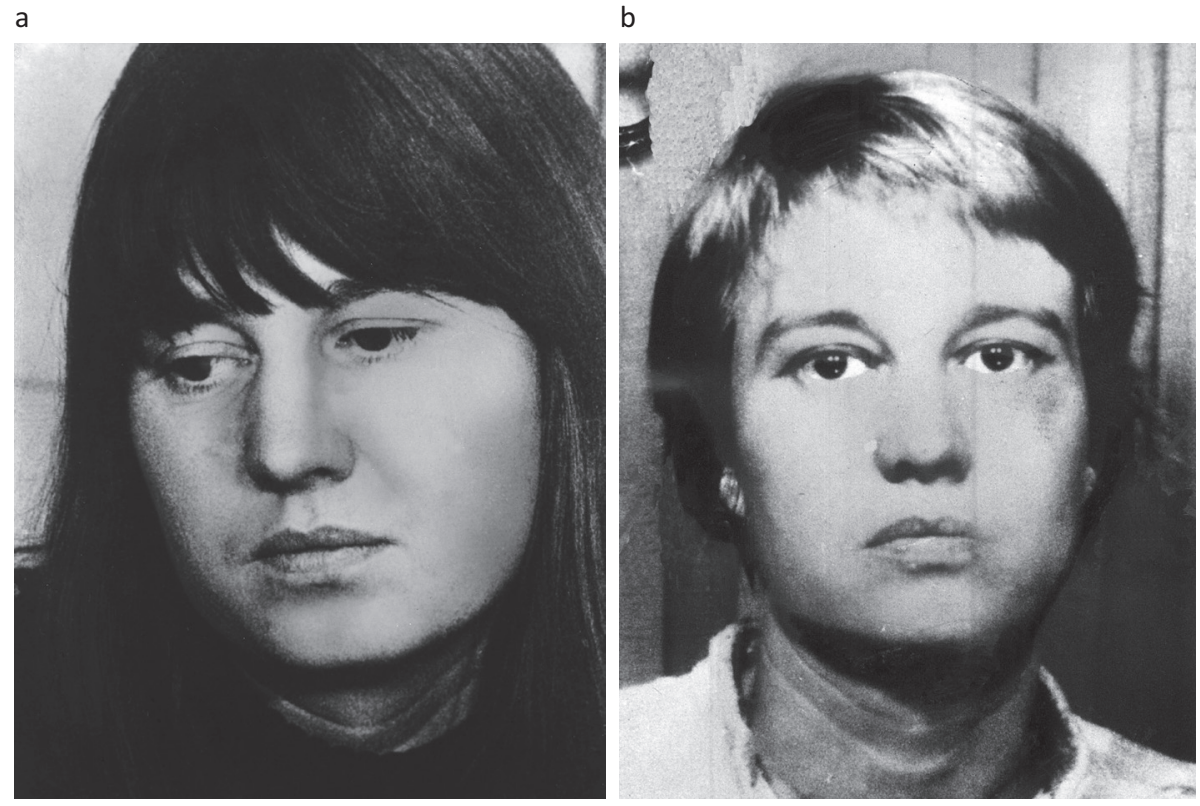

Figure 6 a-b. Meinhof's 'wanted' images, 1970.

As production agreements in 1970s Germany did not explicitly allow the creative reuse of WDR programmes, the broadcaster was 'wary of breaching modern privacy laws or triggering residual claims by the original crew or contributors':

I could only clear the WDR footage in my film for television use...the original intention of the programme sales and distribution in other formats were not foreseen or explicitly agreed to. Cutting the most personal and revealing WDR interviews with Meinhof and Klaus Röhl alters the family dynamic of the story and the pivotal moment where Meinhof chooses revolutionary action over her children. ${ }^{31}$

As a result, the television version of the film is four minutes longer than the DVD version and, due to unavoidable cuts, a different film.

As the German Left tried to politicise inmates in state-run young people's homes, Meinhof developed a radio documentary, Jynette, Irene and Monika (1969) about three girls in a juvenile home into Bambule (1970), a subversive teleplay about a riot in a girls' home. Meinhof defines the concept of Bambule in an expressive commentary in the radio piece:

Bambule means rebellion, resistance, counter-violence, attempts at liberation that mostly end with police intervention and punishment of the instigators and spokespersons, and terror-headlines in [the press]... Explosions of suppressed needs, reactions to an education system, whose violent methods of coercion turn youths into outcasts... ${ }^{32}$

After Baader's escape from prison in May 1970, Meinhof went on the run and the broadcast of Bambule was cancelled by SWR. An opinion poll around this time found that twenty per cent of the population in Hamburg would consider sheltering a member of the RAF for the night, if asked. ${ }^{33}$ 


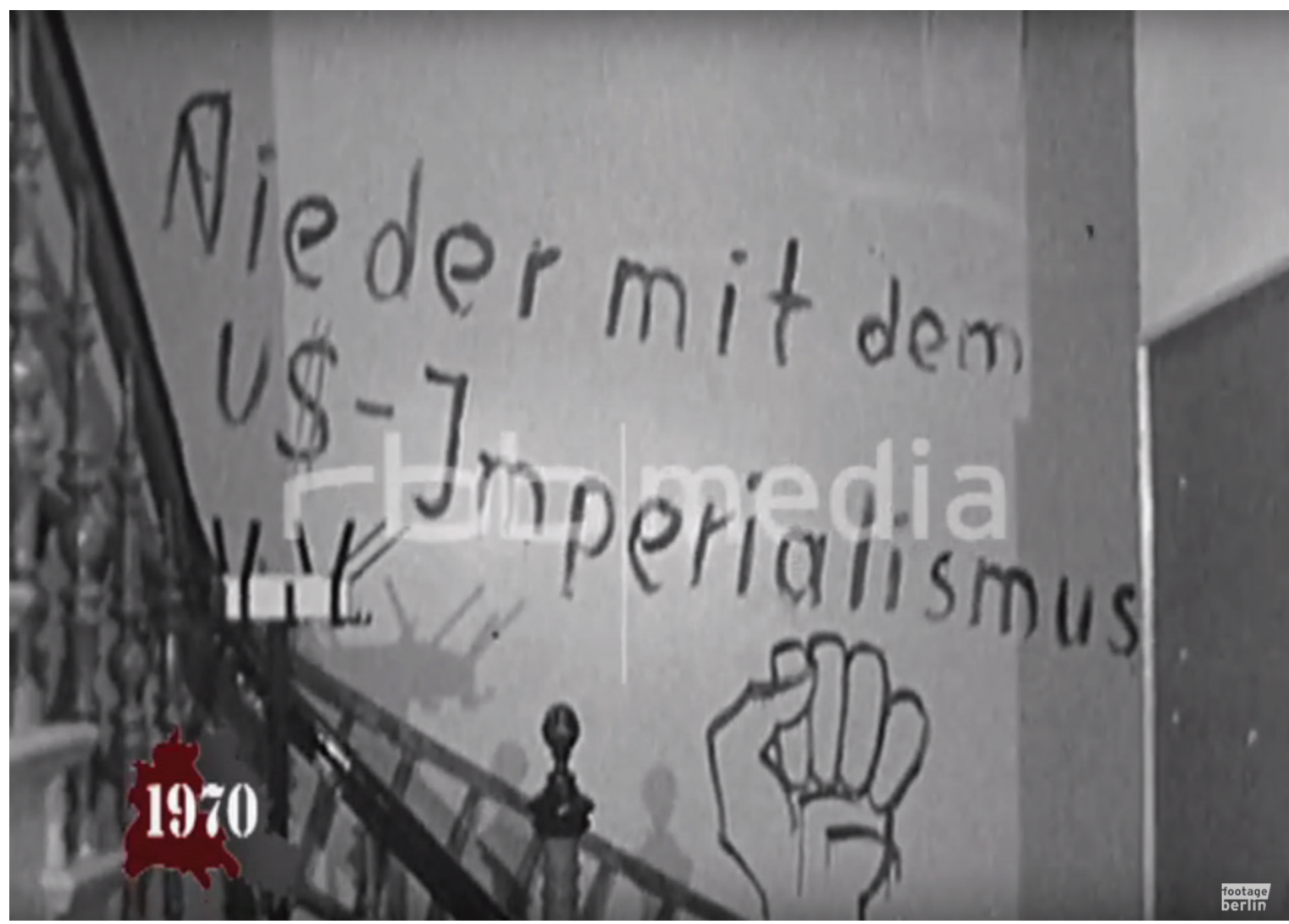

Video 9. Freeing of Andreas Baader (1970)

Leading documentary director Erika Runge got the chance when a barely recognisable Ulrike - a friend from student protest days - turned up at her door one afternoon. After sheltering Meinhof, Runge's phone was tapped and commissioning editors blacklisted her. The habitus of the progressive filmmaker was never to turn away a fallen comrade. The doxa of the commissioning editor and broadcaster was that you could not be seen to support terrorists. Runge's programme proposals were now universally rejected, so she retrained as a psychotherapist. ${ }^{34}$

Public sympathy for what Heinrich Boll termed the war of 'six against sixty million' waned after a series of deadly bombings in April 1972, followed by the arrest of the RAF leaders. Bambule was finally screened in 1997.35

\section{Working with Bettina}

As discussed in O'Sullivan (2013), Bettina Röhl's position as joint-heir to her mother's estate and harsh critic of her mother's post-konkret actions created several obstacles during production. I conceived of the film as the story of two revolutionary mothers seen 'through the eyes of their daughters' but this proved problematic to Röhl, who sought editorial control over how she appeared in the film a year after her initial interview. She withheld photographs and home movies, threatening to withdraw from the project, so I approached two other sources of Meinhof photographs: rival biographer Jutta Ditfurth and her publisher Ullstein Bild, 'part of the Springer empire Meinhof so despised:' 


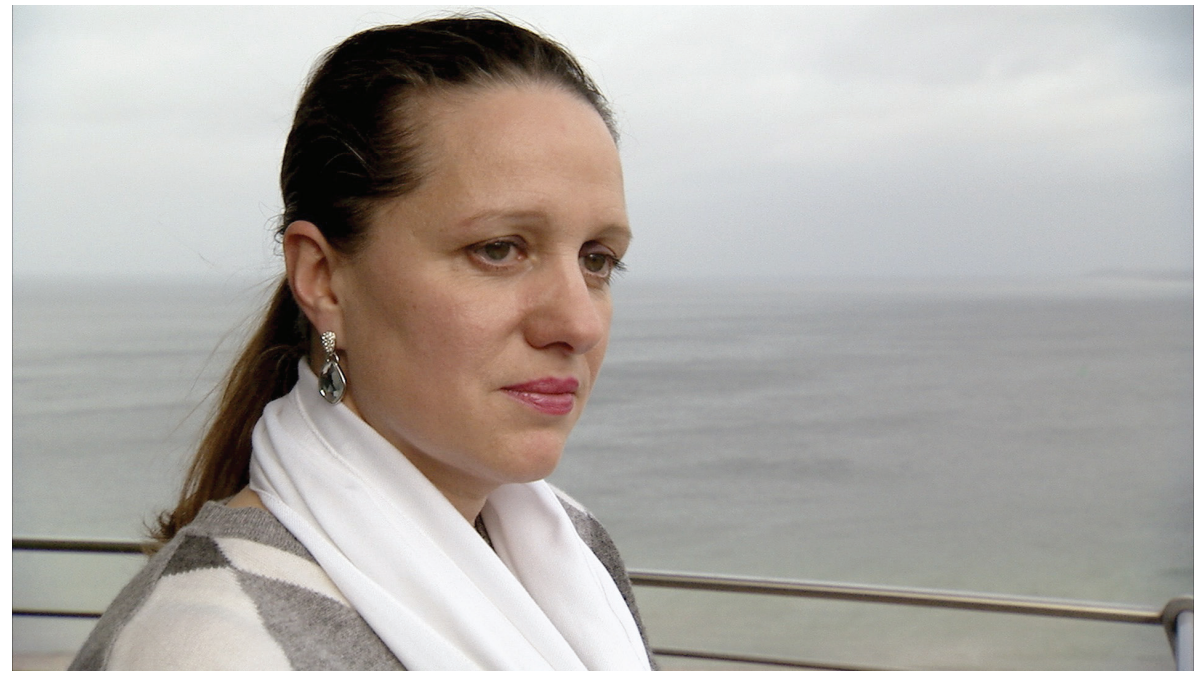

Figure 7. Bettina Röhl in still frame from Children of the Revolution (2010).

Ditfurth, who sees Meinhof as a heroic figure, initially denied me access to her images because of the film's focus on Bettina, who sees her mother as a terrorist who went crazy underground. Several former Red Army Faction (RAF) members also refused to give interviews once Bettina was mentioned, as it was presumed the film would take her line. Access to archive and contributors on this subject is thus highly political, with contributors seeking control of the context in which archive is used or their views are expressed, with a preference for a supportive political line or a cast of like-minded characters. This of course has a profound effect on how the filmmaker can tell the story. Others were more pragmatic, admitting they now earn a living from interviews about the RAF.

When Seven Stories Press published a collection of Meinhof's columns in English, Everybody Talks About the Weather...We Don't, the inclusion of an afterword by Bettina was a condition of publication.

As negotiations with Bettina continued, she informed us that any published use of her mother's words was subject to copyright. We could license mute images from a broadcaster, but if Meinhof was heard speaking, her words should be licensed separately through Bettina and her sister. Quite aside from the questionable legality of this, the enormous extra cost involved was prohibitive. We could surely claim 'fair use' against the Meinhof estate's attempt to effectively silence their mother. ${ }^{36}$

Before Röhl's lawyers could intervene, the film premiered on WDR in May 2011 without any advance publicity and was rebroadcast in 2015. Without the strong support of the commissioning editor at WDR, who insisted on complete editorial independence, the film might not have been completed.

After Meinhof's death in 1976, Stefan Aust - a protégé of Meinhof and Klaus Röhl at konkret, who rescued Bettina and her sister from the RAF in Sicily - made the first documentary about her, Death in Stammheim, and has dominated coverage of the RAF in the German media ever since.

A major two-part documentary, Die RAF (2007) preceded the release of the big-budget movie adaptation of his book, The Baader Meinhof Complex (2008), which eviscerates the theory of Meinhof for the all-action nihilism of Baader. Bettina Röhl and her sister successfully pressured Aust to excise much of their story from the script to protect their privacy. 


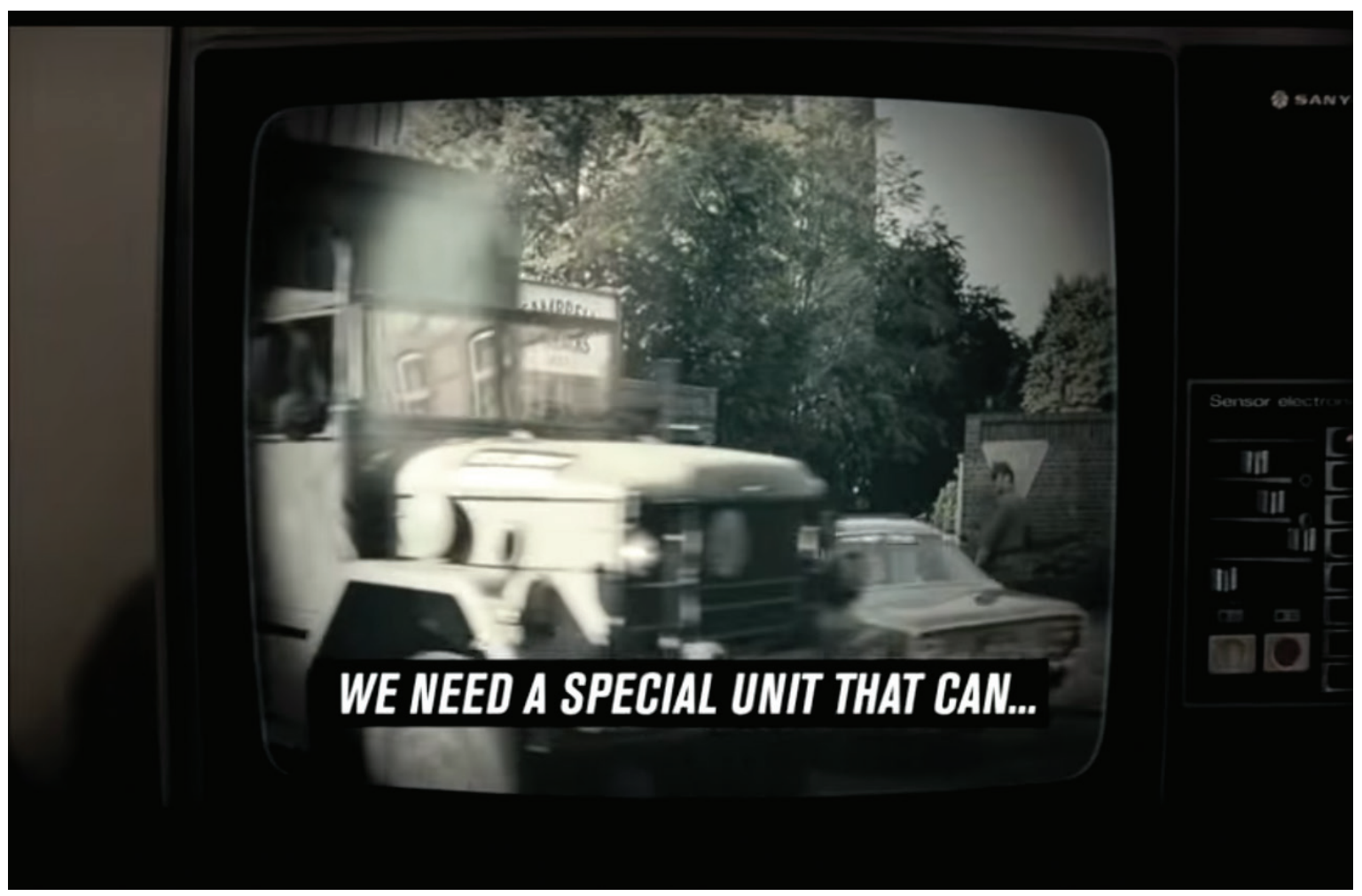

Video 10. Baader Meinhof Complex trailer

The German dimension of my film highlights the partisan feelings about Ulrike Meinhof which still run strong and make re-presenting her story a contentious issue. The rights to her story, her image and sound, and previous documentaries made about her are bound up in production agreements ill-suited to the digital age and controlled by competing players on opposing sides of the ideological spectrum, lauding her as revolutionary martyr or daubing her a crazed terrorist pariah while keenly aware of her commercial value. The filmmaker must try to balance these demands on shrinking budgets while retaining editorial control.

\section{Fusako Shigenobu}

The other female revolutionary explored in my film is Fusako Shigenobu, who left Japan for Lebanon in 1971 to work with the Palestinian revolutionary movement and to become leader of the Japanese Red Army.

As a university student in Tokyo, Shigenobu had been drawn into the 1968 student movement through protests against a rise in tuition fees. As campus demonstrations hardened into militant action, she became a leading figure in the Red Army Faction, which declared war on the state in late 1969, seeking to overthrow capitalism through armed revolution.

After failing to stop the renewal of the Japan - U.S. Security Treaty in 1970, the Japanese student movement broke up and under heavy police surveillance, Shigenobu left for Beirut in February 1971, where she studied the Palestinian revolutionary movement by working in the propaganda unit of the Popular Front for the Liberation of Palestine (PFLP).

The clandestine nature of Red Army Faction activities and the poor preservation record of Japanese broadcasters have left sizeable gaps in the audiovisual record of Japanese revolutionary movements from this period. British Pathé 


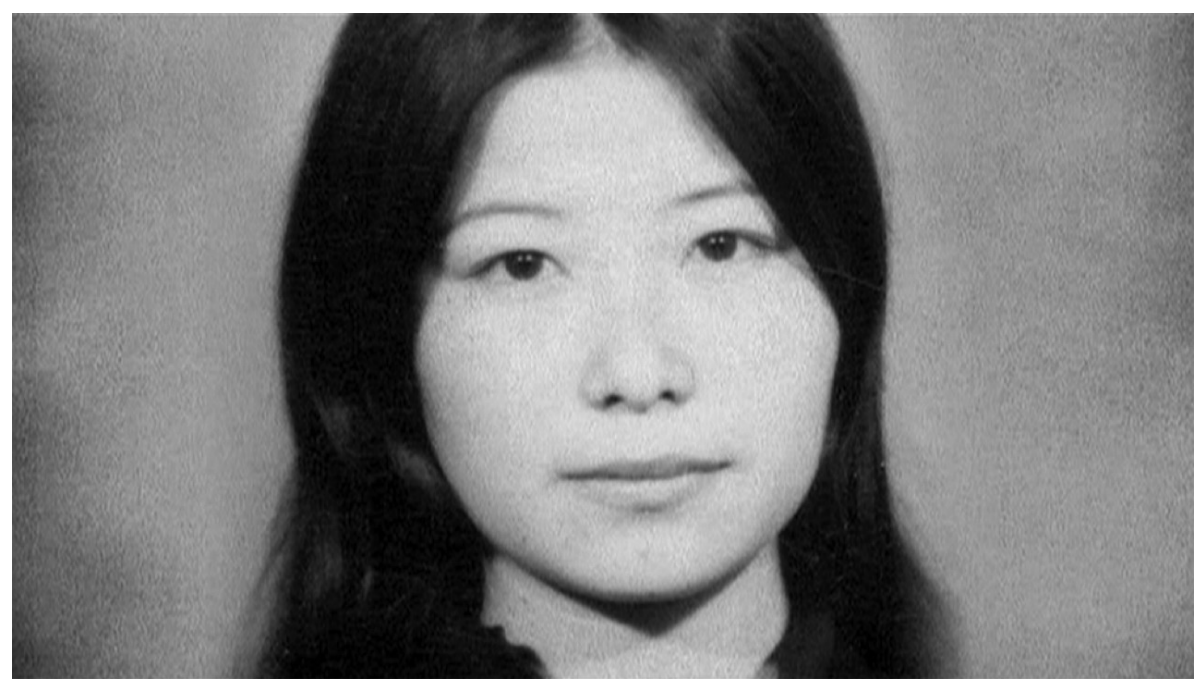

Figure 8. Fusako Shigenobu.

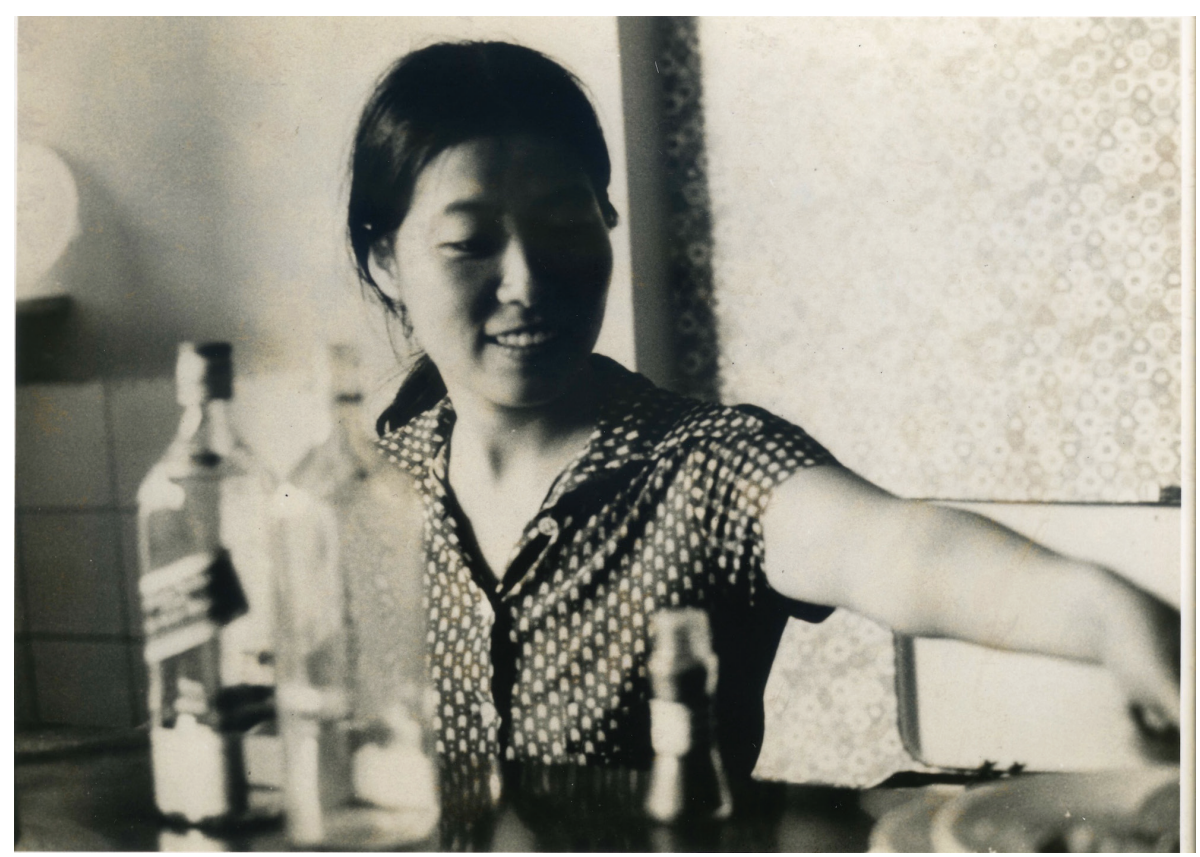

Figure 9. Shigenobu in the Middle East, early 1970s (May Shigenobu).

footage of the Samurais Pop Group (1968) and the Tokyo Rush Hour (1968) exemplify Japanese stereotypes of this era.

These gaps were partially filled in 2009 when AP Archive restored a 'lost archive' of 'twenty-thousand film cans containing 3,500 hours of international news footage... lying dormant for decades deep underground in the Central London bunker from which Eisenhower directed the D-Day landings. ${ }^{37}$

37 Focal International, 2 July 2009, The Lost Archive, http://www.focalint.org/industry-news/news/127/historic-time-capsule-of-news-footagerecovered-by-ap 


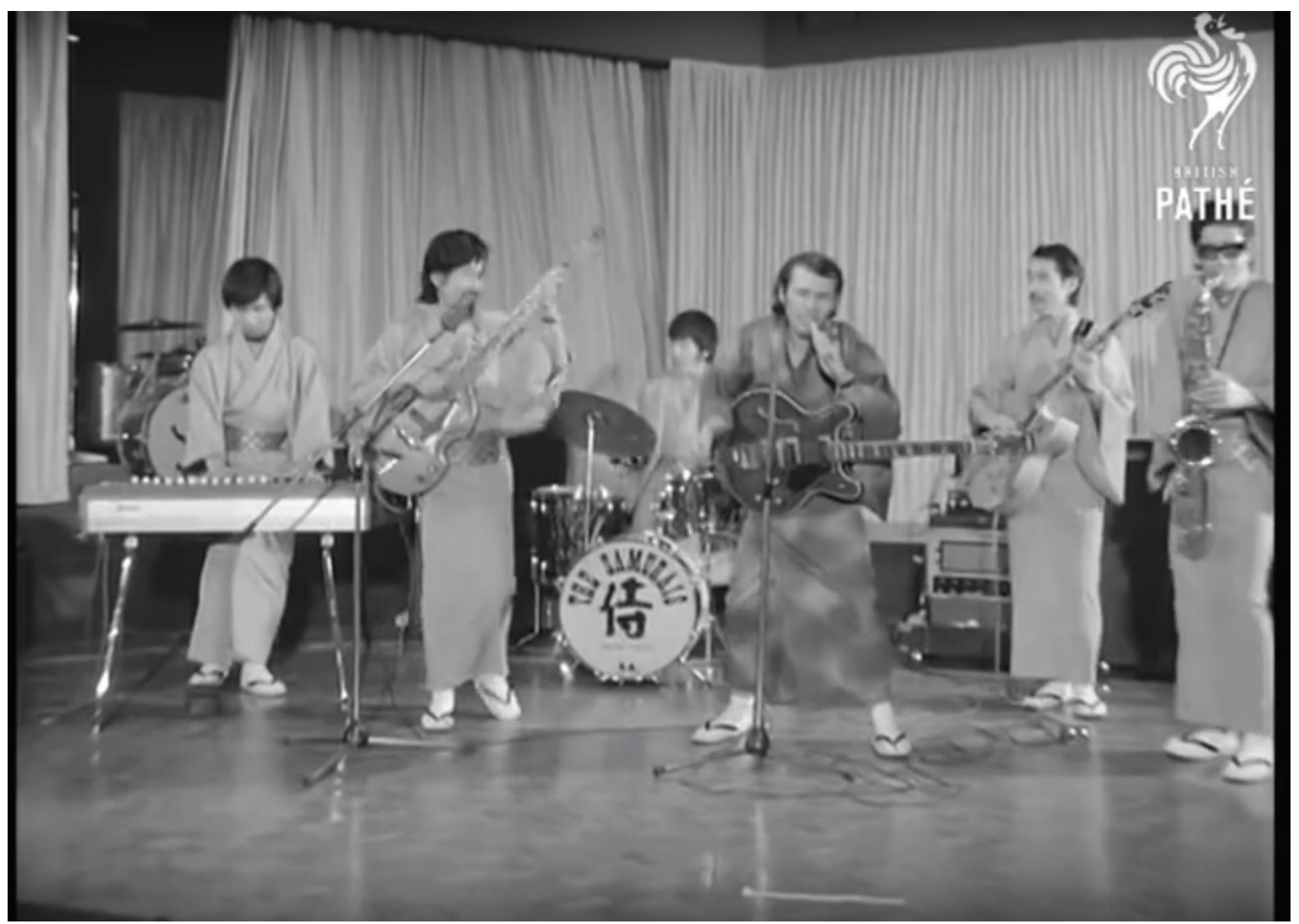

Video 11. Samurais Pop Group

The newly restored collection included rare $16 \mathrm{~mm}$ newsfilm of student demonstrations - images sent from Japan in the late sixties, not seen in Japan since and licensed in pristine HD transfers for my film, as seen in the Japanese trailer below. ${ }^{38}$

There is also very little visible evidence of Fusako Shigenobu's life underground and in exile until her belated arrest in November 2000. As Chanan notes, a film is 'inevitably inscribed with the conditions and circumstances of its production, which also means the negative imprint of certain structuring absences. ${ }^{39}$

In the 'structuring absence' of Shigenobu footage, the filmic representation of her movement is best seen through the work of Masao Adachi, one of Japan's leading experimental filmmakers who wrote scripts for director Koji Wakamatsu in the late sixties, directly inspired by the rise of militant revolutionaries and set against the political ferment of campus occupations and protests against the Vietnam War. Wakamatsu used street demonstrations as a backdrop for highlypoliticised exploitation films, ripped from the headlines and dramatizing the revolutionary struggle.

In Running in Madness, Dying in Love (1969), a protestor takes refuge with his brother, who is a policeman. They fight, a gun is drawn, his brother's wife tries to intervene and the brother dies, so the protestor and the wife try to make it look like suicide and go on the run in the beauty of snow-clad northern Japan. 


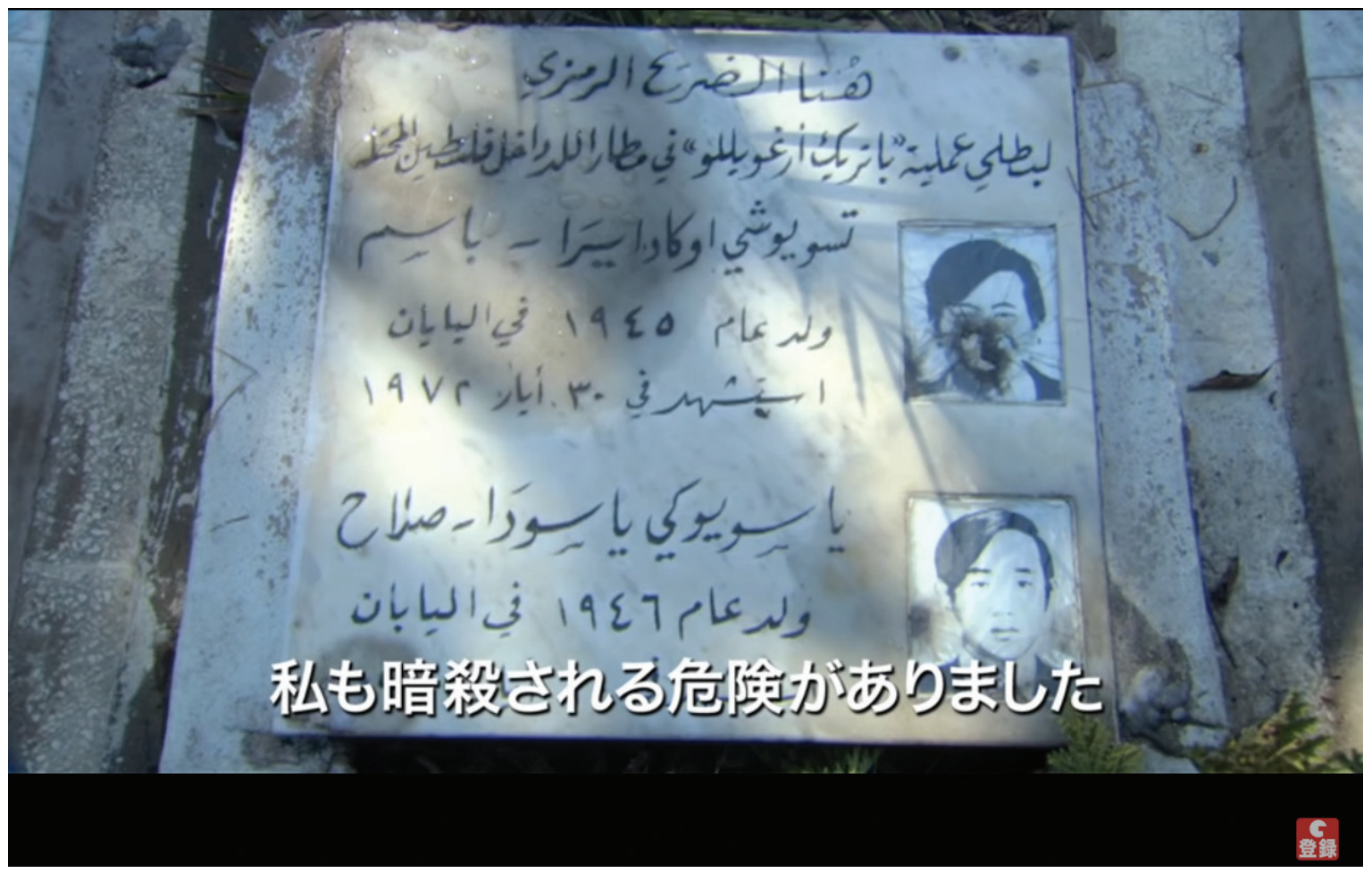

Video 12. Japanese trailer for Children of the Revolution

Sex Jack (1970) opens with cinemascope footage of mass student demonstrations in Tokyo days before the renewal of the Japan - U.S. Security Treaty. A government mole infiltrates a revolutionary cell holed up in a small apartment as they listen to radio reports of attacks on police stations and the Communist headquarters.

Ecstasy of the Angels (1972) follows one of four rival factions within a larger revolutionary group and the opening raid on a US military base was inspired by a real-life Red Army raid a few months earlier. The film culminates with a series of bombing raids across Tokyo, including an attack on the Japanese parliament building.

These fiction films tell us as much about the counter-culture and radical politics of the time as newsreel footage, interpreting the protest movement in freeform, anarchic narratives that play with form and content in revolutionary new ways. I licensed clips from several of these films to contextualise Fusako Shigenobu's story, and also licensed thirty seconds from Wim Wenders' Alice in the Cities (1973), with a monochrome car journey of Alice evoking the attempted kidnapping of Meinhof's daughters by the Baader Meinhof Group.

\section{1 'Shooting a Gun or Shooting with a Camera, It Doesn't Make a Difference to Me" - Masao Adachi40}

In May 1971, after a successful trip to the Cannes Film Festival, Adachi persuaded Wakamatsu to go to Palestine to make 'a film that showed the 'everyday life' of Arab guerrillas, and transformed a 'news documentary' into a radical text

40 'Figures of Dissent: Masao Adachi', Diagonal Thoughts, 20 November 2011, http://www.diagonalthoughts.com/?p=1378 


\section{VIEU}

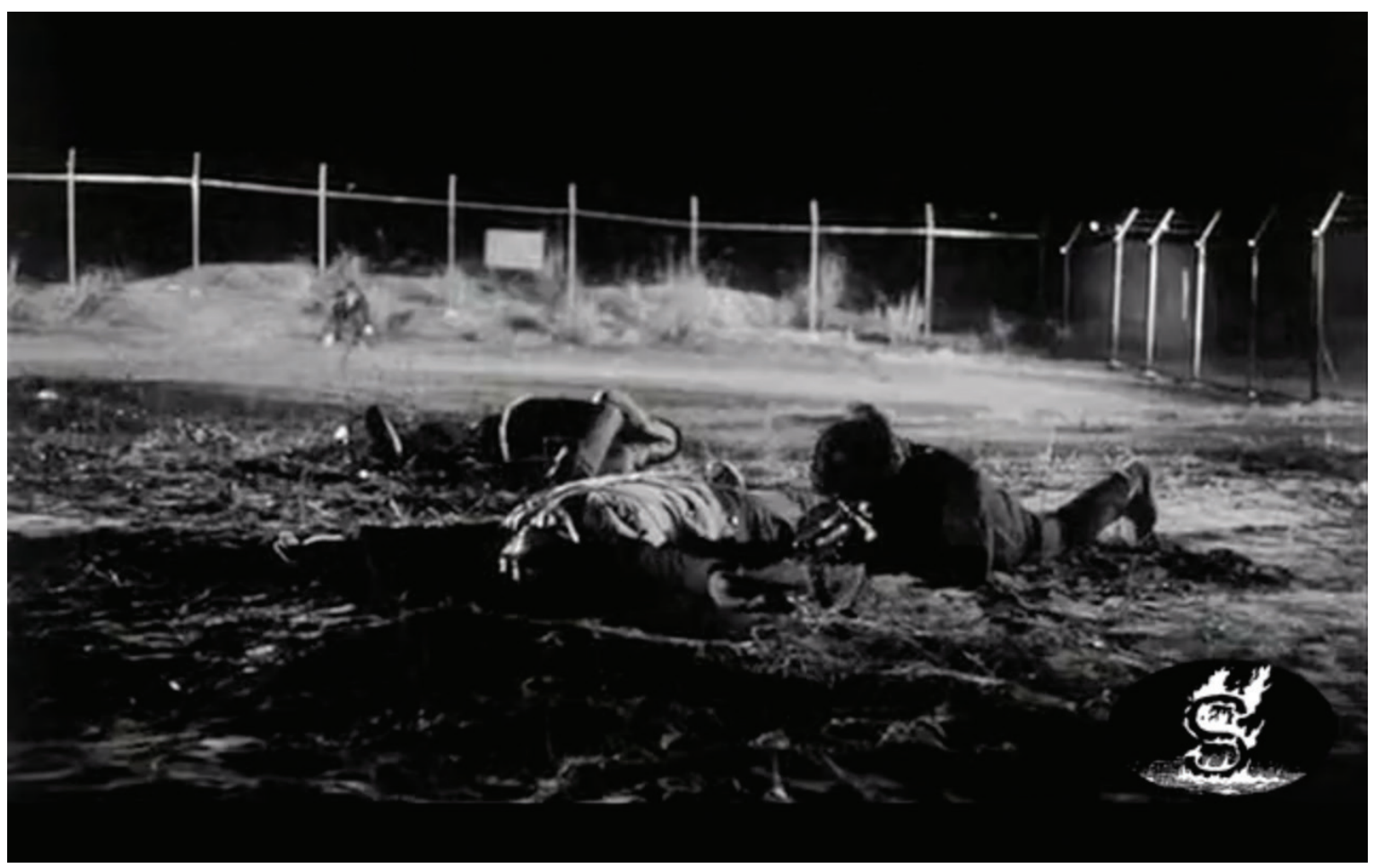

Video 13. Ecstasy of the Angels trailer

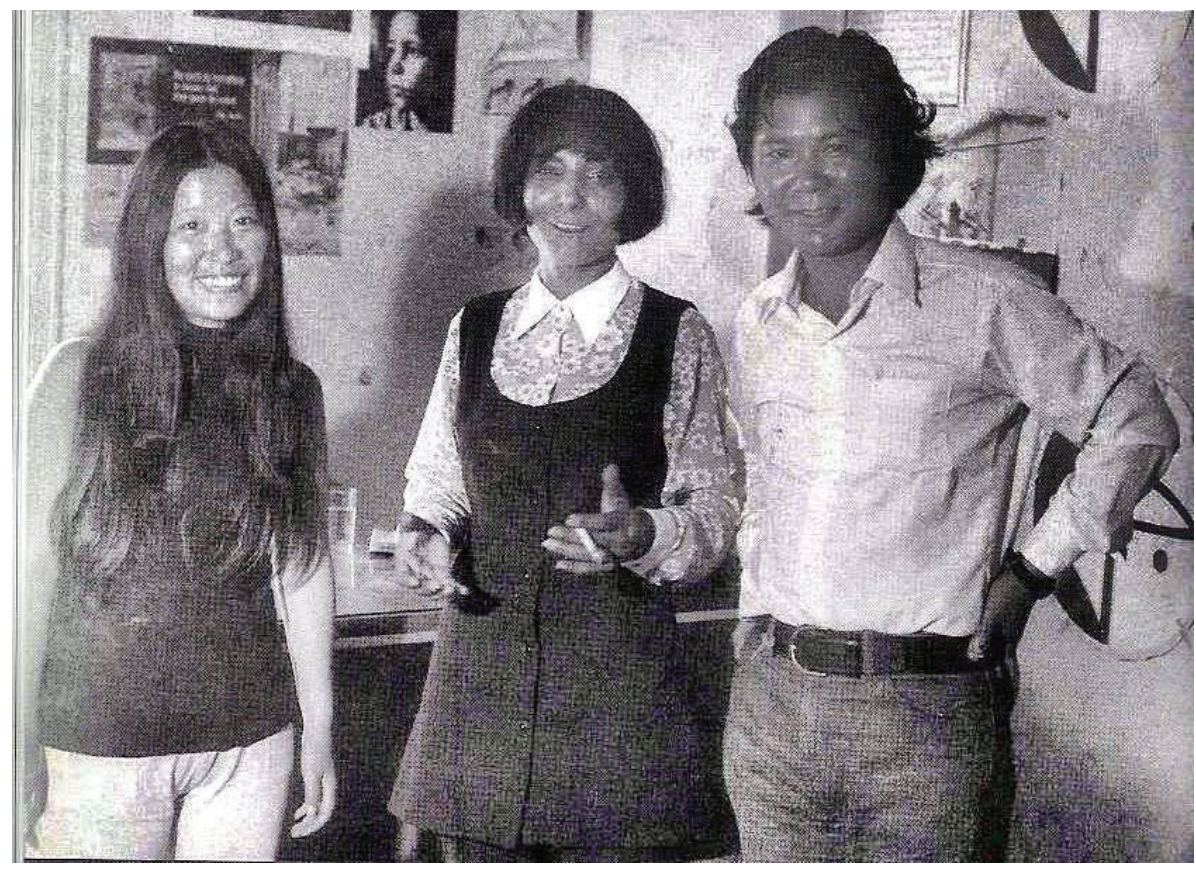

Figure 10. Shigenobu, Leila Khaled, Wakamatsu, Beirut, 1971. 


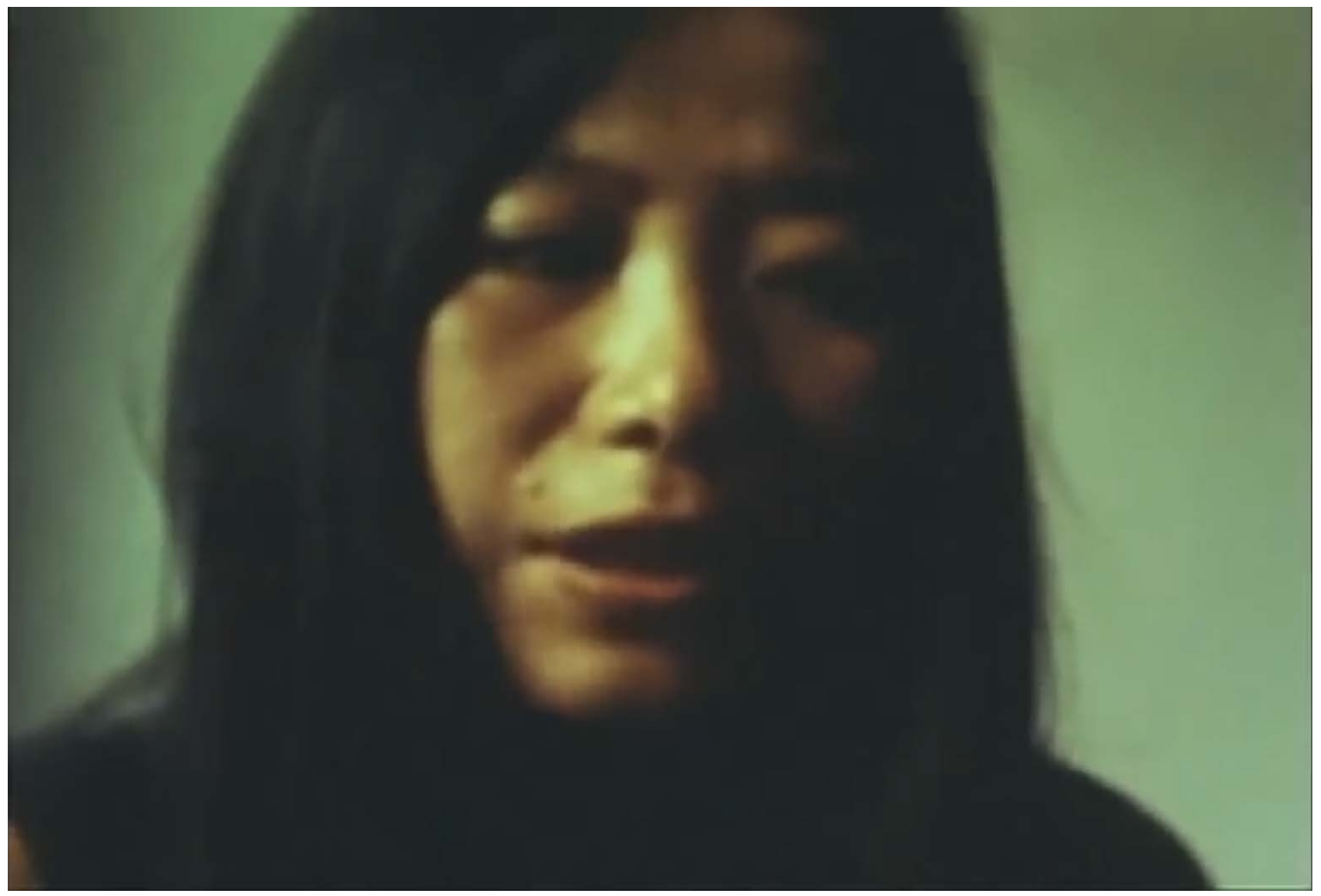

Video 14. Excerpt from Red Army/PFLP: Declaration of World War

for a world revolution.' They contacted Fusako Shigenobu and she acted as a bridge to the PFLP in getting permission to film. ${ }^{41}$

Red Army/PFLP: Declaration of World War (1971) was shot in Jordan and includes Shigenobu's first (non-synch) on-camera interview as well as rare footage of Palestinian fighters on the front line. I licensed four minutes of footage from the film.

Adachi was so impressed by the Palestinian movement, he settled in Lebanon and became a leading figure in the Japanese Red Army. According to German journalist Regine Igel, Stasi files indicate that by 1987, Shigenobu and Adachi were Stasi agents under the cover names 'Bettina' and 'Bruno.'42

Adachi agreed to appear in my film, even though he was initially told by a researcher the title was Children of the Terrorists (a mistranslation). He emerges as the key voice in the Japanese section of the film alongside May Shigenobu.

After quietly working away in the PFLP propaganda department, learning English by listening to the BBC World Service, Shigenobu was thrust onto the world stage in 1972 when three of her Japanese comrades attacked Tel Aviv's Lod airport in a PFLP operation. While the Japanese self-image was humiliated by 'the crazed actions' of its citizens

41 Go Hirasawa, 'Reverse Angle: The 1960s and the Possibility of Radical Underground Film in Japan,' Vertigo, 3, 4, 2007.

42 Regine Igel, 'Leaders of the Japanese Red Army were registered Stasi agents,' 7 November 2010, Telepolis, https://www.heise.de/tp/features/ Fuehrer-der-Japanischen-Roten-Armee-waren-registrierte-Stasi-Agenten-3387477.html 

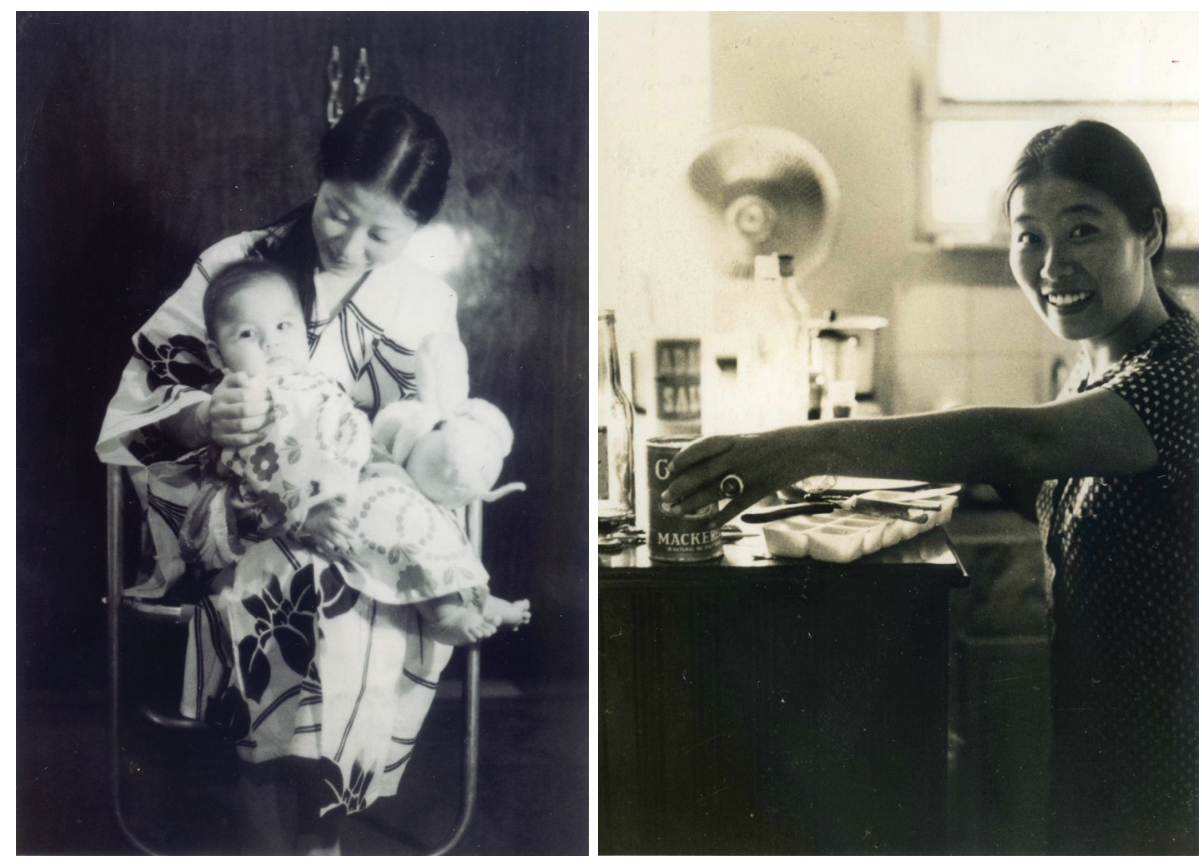

Figure 11 a-b. Fusako Shigenobu, alone and with her daughter May, early 1970s (May Shigenobu).

abroad, within the Arab world, the Japanese were hailed as martyrs. The PFLP claimed responsibility for the attack but Shigenobu was asked to speak on behalf of her dead comrades to show the Japanese dimension.

Under PFLP sponsorship, she was soon mythologised as the Queen of the Japanese Red Army - in reality, a small band of Japanese radicals living communally in exile who shared PFLP aims and were responsible for a series of airport attacks and hijackings between 1972 and 1977.

Shigenobu's only filmed interview as the public face of the Japanese Red Army was given to Fuji Television in August 1973, after the hijacking of a Japanese Airlines plane to Libya. The magazine programme Sanji no Anata ('Your Three O'Clock Show') hosted the 'scoop' in its three o'clock housewives' slot. The opening title cards read: 'Exclusive interview with Fusako Shigenobu revealing the truth about the JAL hijack. Sponsored by Lion toothpaste, Lion hair-oil, Janome sewing machine.' A Lion toothpaste jingle plays as a romantic couple smile at each other in a desert location, before Shigenobu is introduced to discuss the flaming wreckage of a hijacked Japan Airlines plane in the Libyan Desert. Her on-screen caption reads: 'Empress of JRA. Shigenobu Fusako (27).'

As I have written elsewhere, 'Fuji Television quoted me $£ 20,000$ to license one minute of this interview for worldwide use - assuming such 'highly political and sensitive' footage could be cleared - effectively suppressing it forever. ${ }^{33}$

Shigenobu was finally apprehended on a secret visit to Japan in 2000 and while state broadcaster NHK licensed footage of her arrest on more reasonable terms, prison authorities refuse to allow recorded interviews.

In December 2011, Children of the Revolution was invited to screen in the regular film series of the Tokyo Foreign Correspondents' Club and I returned to Japan to seek distribution. Masao Adachi congratulated me on the film and the screening was followed by a press conference with May Shigenobu and myself. 


\section{VIEU}

S.O'Sullivan, Meinhof, Shigenobu, Kennedy

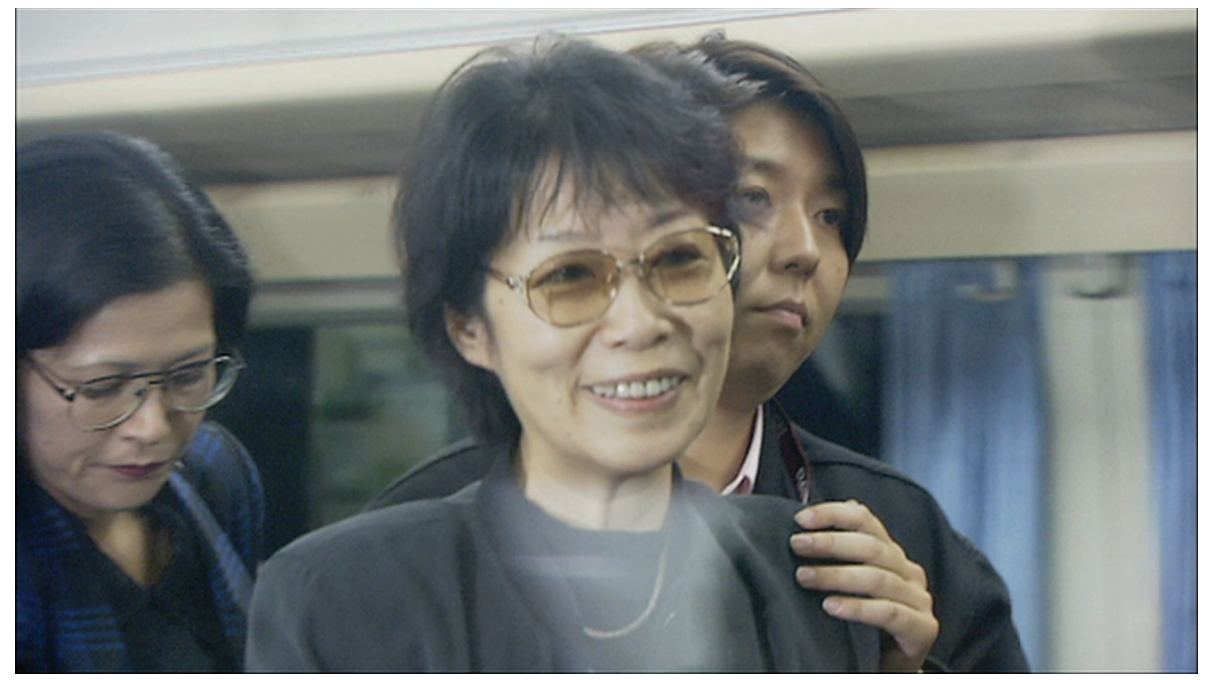

Figure 12. Still frame from Shigenobu arrest footage (NHK, 2000).

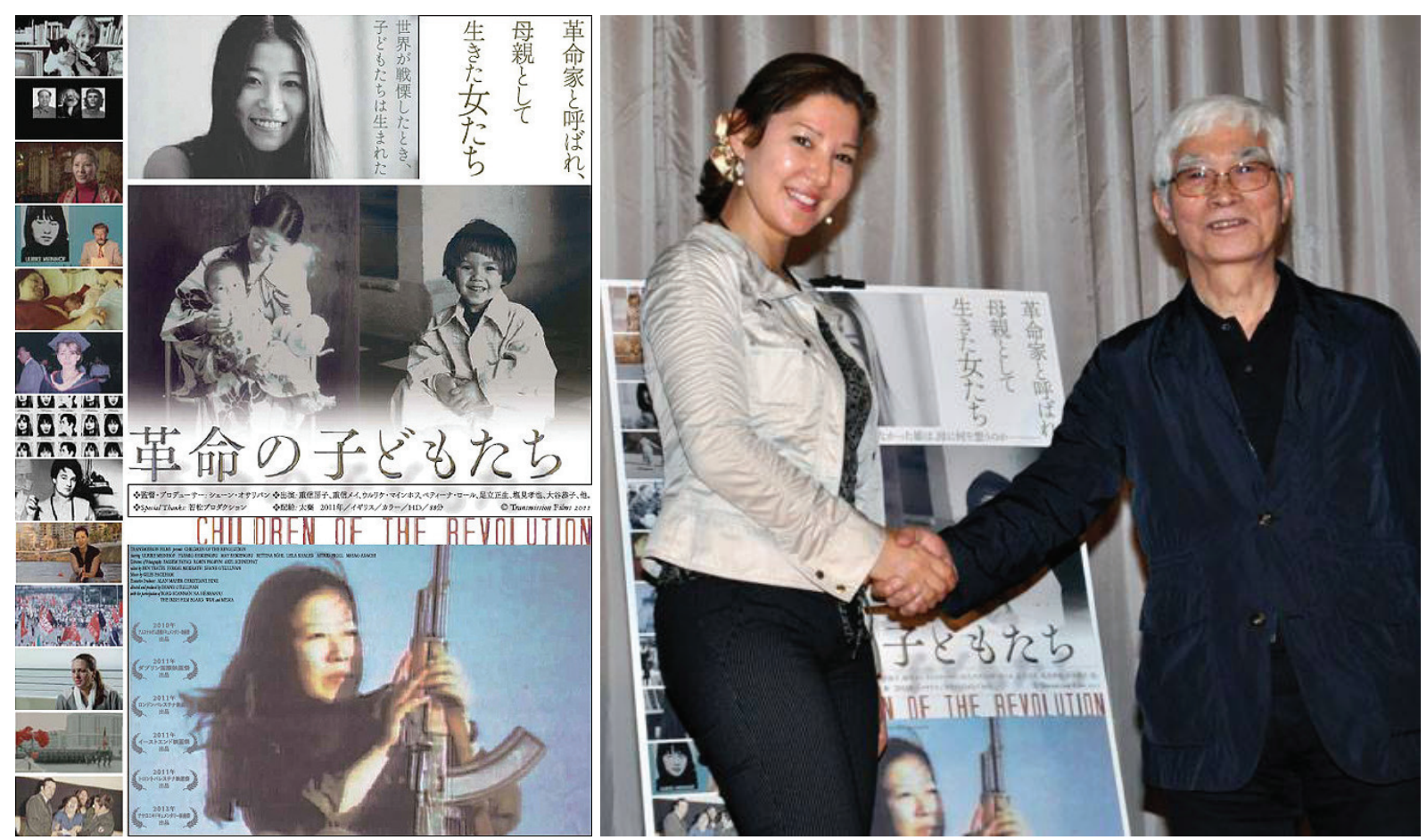

Figure 13 a-b. Japanese poster for Children of the Revolution; Shigenobu and Adachi at a screening.

State broadcaster NHK may occasionally air a very conservative history of the Japanese Red Army but there was no documentary available on DVD in Japan that gave an alternative view of the group, their aims and their history.

An NHK acquisitions executive liked the film and told my sales agent it would work well in Japanese theatres 'but would need adjustments (which perhaps may not be favored by May and Shane) for TV broadcasting in Japan':

My biggest concern is that the 'Fusako side of the story' although being very interesting, seems rather biased, desperate to tell that Fusako is not what she is told to be. Of course, being a family member, that is very 


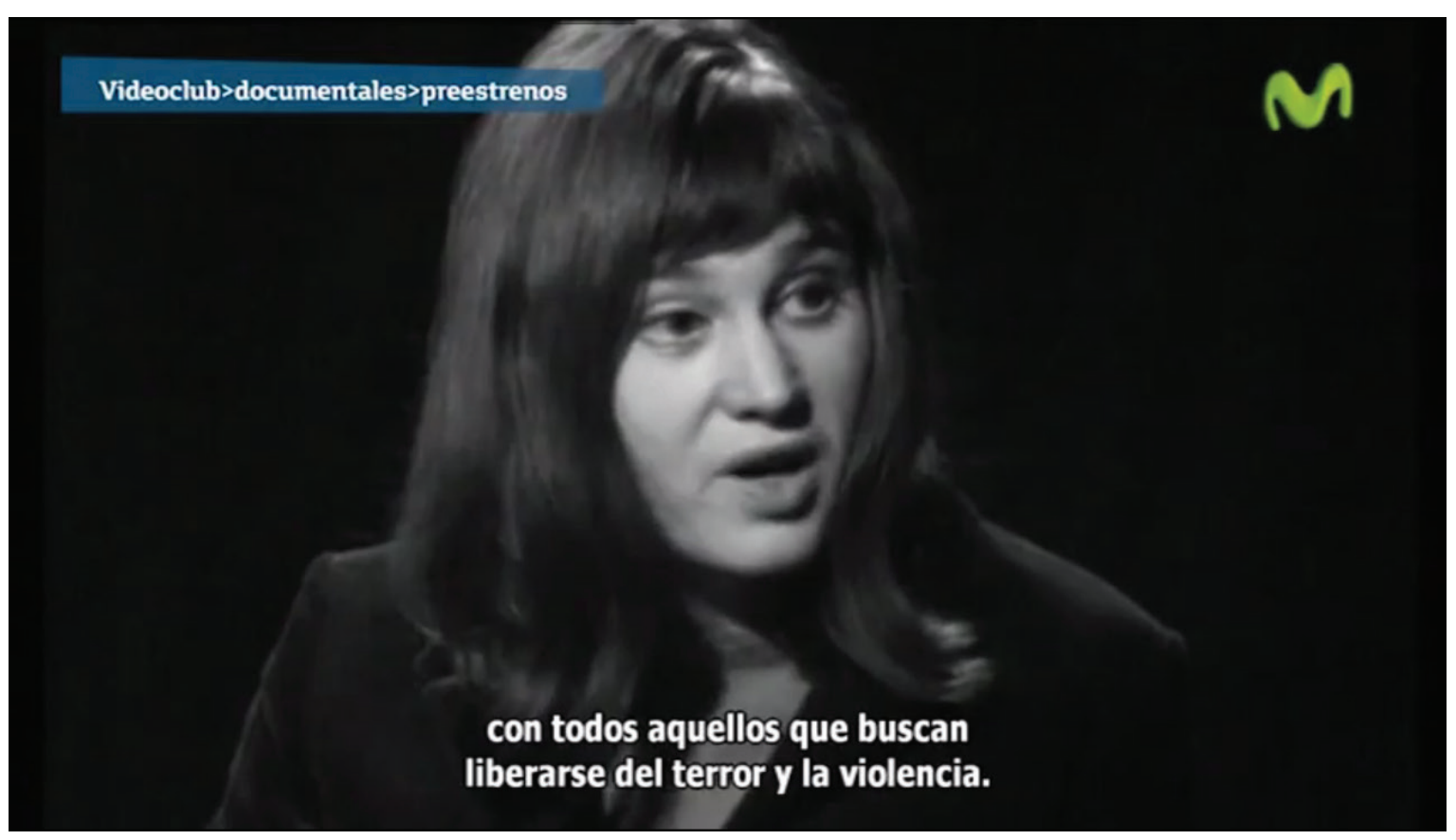

Video 15. Spanish trailer for Children of the Revolution

understandable, however it seems to lack a 'third person point of view'. Considering what has happened by and within the Red Army, in order to be accepted by the Japanese viewers, I think it needs to be more balanced... ${ }^{44}$

Although I was open to changes, this did not progress any further.

Before his death in 2012, Koji Wakamatsu championed the project and with his recommendation, distributor Uzumasa released the film in thirty cinemas across Japan two years later. NHK's News Department interviewed me for an extended segment on the film and May Shigenobu and Masao Adachi led post-screening discussions. While the film has not been broadcast in Japan, it is available there on DVD and has been screened by public broadcasters throughout Europe.

In recent years, filmmakers Eric Baudelaire and Jean-Gabriel Périot have taken a more experimental approach to the stories of Shigenobu, Meinhof and their movements in the films The Anabasis of May and Fusako Shigenobu, Masao Adachi and 27 Years Without Images (2011) and A German Youth (2015). Fusako Shigenobu remains in prison and is due for release in 2021. Her daughter May believes the best way to continue her mother's struggle is through her work as a journalist, reporting on the Palestinian issue.

Aside from television coverage of Shigenobu's arrest and her daughter May's subsequent relocation to Tokyo, the Japanese elements of my film are drawn primarily from the late sixties counterculture in Tokyo, where the revolutionary activities of the Red Army Faction were dramatized in the films of Wakamatsu and Adachi, and the profits were used to make a film about the Palestinian revolution which gave Fusako Shigenobu a platform after her enforced exile to Beirut. The license fees I paid to Wakamatsu for the use of these films were reinvested in one of his final political works on the coup attempt and suicide of author Yukio Mishima in 1970, 11:25 The Day He Chose His Own Fate. 


\section{Conclusion}

These case studies illustrate the important role audiovisual evidence can play in a murder investigation - in the case of Robert Kennedy or Benno Ohnesorg - if investigators are aware of the archive material available and enhance source media using modern technology. Witness testimony can be tested against the audiovisual record and even the most esteemed investigative journalists can be shown to have embroidered their story. Ulrike Meinhof and Fusako Shigenobu challenged the political and economic hegemony of state broadcasters, using film to present alternative representations of their movements in the 'public space,' either within the television commissioning process or through radical independent films. Today, the process of making a film about political history still encounters strong political and economic forces - the power of archives and contributors to withhold archive material and cooperation for political reasons or subject to their editorial control; or the desire to commercially exploit such controversial material by quoting exorbitant license fees, effectively suppressing it forever. Whereas in the seventies, filmmakers like Erika Runge were blacklisted by state broadcasters for their contact with Ulrike Meinhof, the support of my commissioning editor at WDR was crucial in overcoming legal threats from Meinhof's daughter and retaining editorial control over a film which seeks to balance the voices of Meinhof, her daughter Bettina and former RAF comrades like Astrid Proll in telling the personal and political history of 1968 and its aftermath.

\section{Bi o graph y}

Shane O'Sullivan is a Senior Lecturer in Filmmaking at Kingston School of Art, London, with a PhD in Film from Roehampton University. His films include the feature documentaries RFK Must Die (2008), Children of the Revolution (2010) and Killing Oswald (2013). He is also the author of two books, Who Killed Bobby? (2008) and Dirty Tricks: Nixon, Watergate and the CIA (2018). His video essay, Anatomy of a Murder - Sirhan Sirhan and Robert Kennedy, was shortlisted for Best Research Film of the Year in the 2016 AHRC Research in Film Awards. 